Volume $11 \mid$ Issue 2

2001

\title{
Public Health Theory and Practice in the Constitutional Design
}

Lawrence O. Gostin

Follow this and additional works at: https://scholarlycommons.law.case.edu/healthmatrix

Part of the Health Law and Policy Commons

\section{Recommended Citation}

Lawrence O. Gostin, Public Health Theory and Practice in the Constitutional Design, 11 Health Matrix 265 (2001)

Available at: https://scholarlycommons.law.case.edu/healthmatrix/vol11/iss2/4

This Symposium is brought to you for free and open access by the Student Journals at Case Western Reserve University School of Law Scholarly Commons. It has been accepted for inclusion in Health Matrix: The Journal of Law-Medicine by an authorized administrator of Case Western Reserve University School of Law Scholarly Commons. 


\title{
PUBLIC HEALTH THEORY AND PRACTICE IN THE CONSTITUTIONAL DESIGN
}

\author{
Lawrence O. Gostin ${ }^{\dagger}$
}

[Public health law] should not be confused with medical jurisprudence, which is concerned only in the legal aspects of the application of medical and surgical knowledge to individuals .... [P] [Pblic health is not a branch of medicine, but a science in itself, to which, however, preventive medicine is an important contributor. Public health law is that branch of jurisprudence which treats of the application of common and statutory law to the principles of hygiene and sanitary science.

James A. Tobey (1926) ${ }^{1}$

THIS ARTICLE EXAMINES PUBLIC HEALTH theory and practice in the constitutional design. It is important first to understand what I mean by public health and how the field is distinguished from the legal regulation of health care practice and financing. I define public health law as follows:

Public health law is the study of the legal powers and duties of government to assure the conditions for people to be healthy (e.g., to identify, prevent, and ameliorate

$\dagger$ Professor of Law, Georgetown University; Professor of Public Health, the Johns Hopkins University; Director, Center for Law \& the Public's Health at Johns Hopkins and Georgetown Universities (The CDC Collaborating Center Promoting Public Health Through Law; www.publichealthlaw.net). Professor Gostin is on the Institute of Medicine's Board on Health Promotion and Disease Prevention and the Committee on Assuring the Health of the Public in the 21st Century. He is currently chairing the "Turning Point" Public Health Statute Modernization Project designed to draft a model public health law for the states. This article is based on a recent book published by the Milbank Memorial Fund and the University of California Press: Lawrence O. Gostin, Public Health Law: Power, Duty, Restraint (2000).

1 James A. Tobey, Public Health Law: a Manual of Law for SaniTARIANS 6-7 (1926). 
risks to health in the population), and the limitations on the power of the state to constrain the autonomy, privacy, liberty, proprietary, or other legally protected interests of individuals for protection or promotion of community health.

No inquiry is more important to public health law than understanding the role of government in the constitutional design. If I am correct in assuming that public health law principally addresses government's assurance of the conditions for the population's health, then what activities must government undertake? The question is complex, requiring an assessment of duty (what government must do), authority (what government is empowered, but not obligated, to do), and limits (what government is prohibited from doing). In addition, this query raises a corollary question: Which government is to act? Some of the most divisive disputes in public health are among the federal government, the states, and the localities about which government has the power to intervene. ${ }^{2}$

This article views public health through the lens of constitutional law by exploring government duty and authority, the division of powers under our federal system, and the limits on government power. Part I examines constitutional duties, if any, imposed on government. It observes that the Supreme Court sees the Constitution in negative, or defensive, terms and argues that this provides a sterile, uninspiring vision of government obligation. Part II examines governmental powers under the Constitution. While the Court sees few affirmative obligations, it does acknowledge a broad governmental authority to protect the health, safety, and welfare of the population. This Part reviews the emergence of "new federalism" in Supreme Court jurisprudence, altering the power between the federal government and the states. In particular, it inquires whether the Rehnquist Court, by restricting the scope of national authority, is seriously thwarting public health policy and practice. Having examined government duties and powers, Parts III and IV turn to the lim-

${ }^{2}$ As long ago as Martin v. Hunter's Lessee, 14 U.S. (1 Wheat.) 304, 324 (1816), the Supreme Court has puzzled over questions "of great importance and delicacy" in determining whether particular sovereign powers have been granted to the federal government or retained by the states. See also New York v. United States, 505 U.S. 144, 155 (1992) (discussing that, since this country's inception, we have struggled with the grants and limits of the federal, state, and local government powers). 
its on public health powers. Much of the discourse in public health law has been concerned with limits. Part III explores the limits placed on government to refrain from interfering with personal freedoms (e.g., autonomy, bodily integrity, privacy, and liberty). Part IV explores limits relating to economic freedoms (e.g., economic due process, freedom of contract, and regulatory takings). Often, when the government acts to promote the health of the populace, it limits personal or economic freedoms. As a society, we face a trade-off between the common good and individual interests. Parts III and IV explore the conflicts and explain why it is imperative to highly value the collective good of public health.

\section{THE NEGATIVE CONSTITUTION: THE ABSENCE OF GOVERNMENT DUTY TO ASSURE THE CONDITIONS FOR PUBLIC HEALTH}

$[N]$ othing in the language of the Due Process Clause itself requires the State to protect the life, liberty, and property of its citizens against invasion by private actors. The Clause is phrased as a limitation on the State's power to act, not as a guarantee of certain minimal levels of safety and security. It forbids the State itself to deprive individuals of life, liberty, or property without "due process of law," but its language cannot fairly be extended to impose an affirmative obligation on the State to ensure that those interests do not come to harm through other means. Nor does history support such an expansive reading of the constitutional text. ... Its purpose was to protect the people from the State, not to ensure that the State protected them from each other. The Framers were content to leave the extent of governmental obligation in the latter area to the democratic political processes....

William Rehnquist (1989). ${ }^{3}$

Individuals rely on government to organize social and economic life to promote healthy populations. Given the importance of government in maintaining public health (and many (1989).

${ }^{3}$ DeShaney v. Winnebago County Dep't of Soc. Serv., 489 U.S. 189, 195-96 
other communal benefits), one might expect the Constitution to create affirmative obligations for government to act. Yet, by standard accounts, the Constitution is cast purely in negative terms. ${ }^{4}$

The Constitution, it is often said, imposes no affirmative obligation on the government to act, to provide services, or to protect. For the most part, the Bill of Rights is classically defensive, or negative, in character (e.g., the First Amendment declares unequivocally that Congress may not abridge free expression).

The Supreme Court remains faithful to this negative conception of the Constitution, even in the face of dire personal consequences. In DeShaney v. Winnebago County Department of Social Services, ${ }^{5}$ a Wyoming .court granted a divorce and awarded custody of a one-year-old child, Joshua DeShaney, to his father. Two years later, county social workers began receiving reports that Joshua's father was physically abusing him. The suspicious injuries were carefully noted, but the department of social services took no action. Eventually, at four years of age, Joshua was beaten so badly that he suffered permanent brain injuries. He was left profoundly retarded and institutionalized. The DeShaney Court found no constitutional and judicially enforceable government obligation to protect children from harm of which the state is acutely aware. The Court held that, since no affirmative government duty to protect exists, citizens have no constitutional remedy under the due process clause. $^{6}$

The Supreme Court has applied this line of reasoning in cases that bitterly divided the Court and the nation. In Webster v. Reproductive Health Services, ${ }^{7}$ the majority saw no government obligation to provide "services" in this case, medical "services" for the poor, ${ }^{8}$ when a Missouri statute barred state employees from performing abortions and banned the use of

${ }^{4}$ See Susan Bandes, The Negative Constitution: A Critique, 88 MicH. L. REv. 2271 (1990) (describing the constitutional obligations of the government as prohibitory); Mark Tushnet, An Essay on Rights, 62 TEX. L. REv. 1363 (1984).

${ }^{5} 489$ U.S. 189 (1989).

${ }^{6}$ Id. at 197.

${ }^{7} 492$ U.S. 490 (1989) (holding that states are not required to provide facilities for abortions).

${ }^{8}$ See generally Laurence $\mathrm{H}$. Tribe, The Abortion Funding Conundrum: Inalienable Rights, Affirmative Duties, and the Dilemma of Dependence, 99 HARv. L. REv. 330 (1985). 
public facilities for such, Referring to DeShaney, the Court rejected a positive claim for basic government services: "[O]ur cases have recognized that the Due Process Clauses generally confer no affirmative right to governmental aid, even where such aid may be necessary to secure life, liberty, or property interests of which the government itself may not deprive the individual." According to the Court, if "no state subsidy, direct or indirect, is available, it is difficult to see how any procreational choice is burdened by the State's ban on the use of its facilities or employees for performing abortions." 10 The majority found irrelevant the fact that, if a woman is poor, her only realistic access to medical services may be through government assistance.

In DeShaney, Webster, and other cases ${ }^{11}$ an increasingly conservative judiciary has disavowed the idea of positive social rights by finding that the due process clause affords no affirmative obligations, but only negative liberties; government inaction is constitutionally immaterial, and government's failure to act brings no constitutional remedy. This negative theory of constitutional design, though well accepted, is oversimplified and, in the words of Justice Blackmun, represents "a sad commentary upon American life, and constitutional principles...."12

A weakness of the negative theory of constitutional law is that its distinctions, as between action and inaction, are difficult to sustain. The Supreme Court has repeatedly held that government has no obligation to prevent harms to health or to provide services to ameliorate ill-health; that is, a government act that causes harm is actionable, while government passivity in an existing state of affairs is not. Although the Court appears to know instinctively what constitutes a governmental act, the difference between an act and an omission is often difficult to de-

${ }^{9}$ Webster, 492 U.S. at 507 (1989) (quoting DeShaney v. Winnebago County Dep't of Soc. Serv., 489 U.S. 189, 196 (1989)).

${ }^{10}$ Id. at 510 .

${ }^{11}$ See, e.g., Johnson v. Dallas Indep. Sch. Dist., 38 F.3d 198 (5th Cir. 1994) (finding students have no constitutional right to affirmative protection from violence at school); Archie v. City of Racine, 847 F.2d 1211 (7th Cir. 1988) (denying liability when 911 dispatcher gave incorrect advice and failed to dispatch an ambulance for a caller who then died); Estate of Gilmore v. Buckley, 787 F.2d 714 (1st Cir. 1986) (finding no liability when state officials released a dangerous mental patient who they knew had threatened a particular person, leading to her murder).

${ }^{12}$ DeShaney v. Winnebago County Dep't of Soc. Serv., 489 U.S. 189, 213 (1989) (Blackmun, J., dissenting). 
termine. ${ }^{13}$ Any government failure to act is usually embedded in a series of affirmative policy choices (e.g., which agency will be established; the agency's objectives and how its staff will be trained; what resources, if any, will be devoted to certain problems). When government deliberately chooses to intervene (or to allocate scarce resources) in one sphere, and conspicuously fails to perform in another, can that fairly be characterized as "inaction"?

Another problem with the negative constitution is that citizens rely on the protective umbrella of the state. When the state establishes an agency to detect and prevent child abuse (or to prevent any other cause of injury or disease), it promises, at least implicitly, that it will respond in cases of obvious threats to health. If an agency holds itself out to the public as a defender of human health, and citizens justifiably rely on that protection, is government "responsible" when it knows a substantial risk exists, fails to inform citizens so they might initiate action, and passively avoid a state response to that risk?

Finally, judicial refusal to examine government's failure to act, irrespective of the circumstances, leaves the state free to abuse its power and cause harm to citizens. Government more often exerts its power, and its potential to harm, by withholding services in the face of undeniable threats to health. ${ }^{14}$ The state's neglect of the poor and vulnerable, its calculated failure to respond to obvious risk, or its arbitrary or discriminatory enforcement of public health law is a certain, and direct, cause of harm. Seidman and Tushnet suggest that the Fourteenth Amendment's historical purpose was to expand government's power to contend with private acts of violence. This history is consistent with the view that "the state is inflicting ... deprivation [of life, liberty, or property] when officials organize their activities so that people fall prey to private violence." 15 A constitutional rule, moreover, that punishes government misfeasance (when the state intentionally or negligently causes harm)

${ }^{13}$ Susan Bandes, supra note 4, at 2278 (discussing the difficulty in determining governmental action/inaction).

${ }_{14}$ See Seth F. Kreimer, Allocational Sanctions: The Problem of Negative Rights in a Positive State, 132 U. PA. L. REv. 1293, 1295-96 (1984) (claiming the government exerts its power by withholding important benefits rather than through force or criminal sanctions).

15 LouIs M. SEIDMAN \& MARK V. TUSHNET, REMNANTS OF BELIEF: CONTEMPORARY CONSTITUTIONAL ISSUES 52 (1996). 
but not non-feasance (when the state simply does not act) provides an incentive to withhold services and interventions. ${ }^{16}$ In many contexts, the rule requiring state action as a prior condition for judicial review provides a limited and uninspired vision of the Constitution.

\section{U. GOVERNMENTAL POWER TO ASSURE THE CONDITIONS FOR PUBLIC HEALTH}

The Supreme Court, as we have just seen, has a constricted vision of governmental duty to protect the public's health. The Court, however, has recognized a substantial governmental power to assure the conditions for the population's health. This Part examines the Court's jurisprudence in relation to federal and state public health powers.

\section{A. Federal Public Health Powers}

Article I, section one of the Constitution endows Congress with the "legislative Powers herein granted," not with plenary legislative authority. It is well known that the federal government must draw its authority to act from specific, enumerated powers. Thus, before an act of Congress is deemed constitutional, two questions must be asked: Does the Constitution affirmatively authorize Congress to act, and does the exercise of that power improperly interfere with any constitutionally protected interest?

The United States is a government of limited powers but, in reality, its powers are not as limited as some of the Framers might have imagined. The federal government possesses considerable authority to act and exerts extensive control in the realm of public health and safety. ${ }^{17}$ The Supreme Court, through

${ }^{16} I d$. at 54.

${ }^{17}$ Congress derives its sweeping powers, in part, from Article $I, \S 8$ of the Constitution: Congress may "make all Laws which shall be necessary and proper for carrying into Execution" all powers vested by the Constitution in the government of the United States. The "necessary and proper" clause, the subject of many great debates in American history, incorporates within the Constitution the doctrine of implied powers. Chief Justice Marshall's famous construction of the necessary and proper clause in $\mathrm{McC}$ ulloch v. Maryland suggests that Congress may use any reasonable means not prohibited by the Constitution to carry out its express powers: "Let the end be legitimate, let it be within the scope of the constitution, and all means which are appropriate, which are plainly adapted to that end, which are not prohibited, but consistent with the letter and spirit of the constitution, are constitutional." McCulloch v. Maryland, 17 U.S. (4 Wheat.) 316, 421 (1819). 
an expansive interpretation of Congress' enumerated powers, has enabled the federal government to maintain a vast presence in public health-in matters ranging from biomedical research and the provision of health care to the control of infectious diseases, occupational health and safety, and environmental protection (see Table 1, Appendix A).

The Constitution delegates diverse authority to the United States. ${ }^{18}$ The power to tax, spend, and regulate interstate commerce afford the federal government potentially immense public health authority.

1. The Power to Tax Is the Power to Raise Revenue, Regulate Risk Behavior, and Induce Health-Promoting Behaviors

No attribute of sovereignty is more pervading [than taxation], and at no point does the power of government affect more constantly and intimately all the relations of life than through the exactions made under it.

Thomas M. Cooley $(1890)^{19}$

Article I, section eight states that "[t]he Congress shall have Power To lay and collect Taxes, Duties, Imposts and Excises, to pay the Debts and provide for the common Defence and general Welfare of the United States." On its face, the power to tax has a single, overriding purpose-to raise revenue to provide for the good of the community. Absent the ability to

${ }^{18}$ The enumerated powers of Congress include the power to: tax, borrow money, regulate interstate commerce, establish rules for naturalization and bankruptcies, coin money, punish counterfeiting, establish Post Offices, promote the progress of science and art by securing rights in intellectual property, constitute the judiciary, punish piracy and felony on the High Seas, declare war, provide for and maintain (in various ways) the military of the United States, and exclusively legislate in the District of Columbia. Congress, moreover, may enact all laws which are "necessary and proper" for carrying out its enumerated powers. U.S. CoNST. art. I, § 8. Apart from Article I, $\S 8$, the provisions of the Constitution delegating power to Congress include: Article IV (prescribing the manner in which full faith and credit shall be given to the acts of every State); Article V (ratification of Constitutional Amendments); Sixteenth Amendment (national income tax); and other Amendments that recognize individual rights that authorize Congress to enforce their provisions by "appropriate legislation."

19 Thomas M. CoOley, Treatise on the Constitutional Limitations WHICH REST UPON THE LEgISLATIVE POWER OF THE AMERICAN UNION, 587 (6th ed. 1890). 
generate sufficient revenue, the legislature could not provide services such as transportation, education, medical services to the poor, sanitation, and environmental protection. Historically, constitutional constraints were imposed on Congress' revenueraising capacity. Drawing a distinction between direct taxes (imposed upon property) and indirect taxes (imposed on the performance of an act), ${ }^{20}$ the Supreme Court, at the turn of the century, declared unconstitutional a federal income tax. ${ }^{21}$ The Sixteenth Amendment, ratified in 1913, restored the federal income tax and made possible an almost limitless revenue-raising potential within the federal government.

The power to tax is closely aligned with the power to spend. ${ }^{22}$ Economists regard congressional decisions to provide tax relief for certain activities as indirect expenditures because government is, in fact, subsidizing the activity from the national treasury. Economists project, for example, that favorable tax treatment afforded to employer-sponsored health care plans will cost the federal government $\$ 438$ billion between the years 1999 and 2003. ${ }^{23}$

The taxing power, while affording government the financial resources to provide public health services, has another, equally important, purpose. The power to tax is also the power to regulate risk behavior and influence health-promoting activities. ${ }^{24}$ Virtually all taxes achieve ancillary regulatory effects by imposing an economic burden on the taxed activity or providing economic relief for certain kinds of private spending. Consequently, the tax code provides incentives and disincentives to perform, or to refrain from performing, certain acts. The more onerous the tax (in terms of the economic and administrative

${ }^{20}$ See U.S. CONST. art. I, § 9: "No Capitation, or other direct, Tax shall be laid, unless in Proportion to the Census...." This "apportionment" requirement made it burdensome for the federal government whenever the Supreme Court ruled that a tax, for constitutional purposes, was "direct."

${ }^{21}$ See Pollock v. Farmers' Loan \& Trust Co., 157 U.S. 429 (1895) (holding that income tax, because the source of income is, in part, property, is unconstitutional unless apportioned).

${ }_{22}$ Consider excise taxes that have a trust fund with a related public health purpose; for example, the tax on the sale or use of domestic mined coal goes to the Black Lung Benefits Act, 30 U.S.C.A. \$ 901 (West Supp. 2000).

${ }^{23}$ See OFFICE OF MANAGEMENT \& BUDGET, BUDGET OF THE UNITED STATES GOVERNMENT: FISCAL YEAR 1999, at 218 (1998); see also HENRY J. AARON, SERIOUS aNd UNSTABle CoNdition: FinanCing AMERICA's Health CARE 67-68 (1991).

${ }^{24}$ See generally R. ALTON LEE, A History OF REgulatory TAXation 1-11 (1973) (discussing the relationship between police power and taxing power). 
costs) or the more generous the tax relief, the more powerful the ancillary regulatory effects.

The taxing power is a primary means for achieving public health objectives. As Fox and Schaffer observe, "tax law and health policy come together" to affect fundamentally the health of the community. ${ }^{25}$ Broadly speaking, the tax code influences health-related behavior through tax relief and tax burdens. Tax relief encourages private, health-promoting activity and tax burdens discourage risk behavior.

Through various forms of tax relief (e.g., excluding benefits from taxable income, deducting spending from gross income, and providing credits against tax owed), government provides incentives for private activities that it views as advantageous to community health. Employer-sponsored health plans, for example, receive generous tax incentives. By excluding employer contributions for health benefits from federal and state taxable income, ${ }^{26}$ the Internal Revenue Code "deeply affect[s] how health care is provided in the United States, to whom it is provided, and who provides it."27 Similarly, federal and state income and property tax exemptions afforded to the nonprofit sector demonstrate a distinct government preference for nonprofit over investor-owned health care institutions. Government preferences for nonprofit entities have significant effects on hospital care in America. ${ }^{28}$ The tax code influences private health-related spending in many other ways: encouraging child care to enable parents to enter the work force, ${ }^{29}$ inducing investment in low income housing, ${ }^{30}$ promoting clinical testing of

${ }^{25}$ Daniel M. Fox \& Daniel C. Schaffer, Tax Policy as Social Policy: Cafeteria Plans, 1978-1985, 12 J. HEALTH Pol., POL'Y \& L. 609, 610 (1987); see also Daniel M. Fox \& Daniel C. Schaffer, Tax Administration as Health Policy: Hospitals, the Internal Revenue Service, and the Courts, $16 \mathrm{~J}$. HEALTH POL., POL'Y \& L. 251 (1991).

${ }^{26}$ See 26 U.S.C.A. $\S 162$ (West Supp. 2000) (exempting employee provided health benefits from taxes).

${ }^{27}$ Fox \& Schaffer, supra note 25, at 610.

${ }^{28}$ See generally M. Gregg Bloche, Health Policy Below the Waterline: Medical Care and the Charitable Exemption, 80 MINN. L. REV. 299 (1995) (examining the conceptual premises and the effects of federal tax exemption for nonprofit hospitals).

${ }^{29}$ See 26 U.S.C.A. $\$ 21$ (West Supp. 2000) (allowing taxpayers to subtract a percentage of money spent on child care from overall tax liability).

${ }^{30}$ See 26 U.S.C.A. \$ 42 (West Supp. 2000) (designating low income housing credit). 
pharmaceuticals for rare diseases; ${ }^{31}$ and stimulating charitable spending for research and care in areas such as heart disease, cancer, and mental retardation. ${ }^{32}$

Public health taxation also regulates private behavior by economically penalizing risk-taking activities. Tax policy discourages a number of activities that government regards as unhealthy or dangerous. ${ }^{33}$ Consider excise or manufacturing taxes on tobacco, ${ }^{34}$ alcoholic beverages, ${ }^{35}$ or firearms. ${ }^{36}$ Tax policy also penalizes certain behavior regarded as "immoral" such as gambling. ${ }^{37}$ Finally, tax policy influences individual and business decisions that adversely affect health or the environment, such as taxes on gasoline ${ }^{38}$ or on ozone-depleting chemicals ${ }^{39}$ that contribute to environmental degradation. It is difficult to imagine a public health threat caused by human behavior or business activity that cannot be influenced by the taxing power.

The taxing power provides an independent source of federal legislative authority. Congress may regulate through the tax system for purposes that may not be authorized under its enumerated powers. The Supreme Court, in its early jurisprudence, was concerned about federal taxes that were designed to punish or regulate rather than to raise revenue. Thus, the Court distinguished between revenue-raising taxes, which it upheld, and purely regulatory taxes, which it found constitutionally troubling. ${ }^{40}$ This distinction, however, has all but disappeared. For

${ }^{31}$ See 26 U.S.C.A. $\$ 45 C$ (West Supp. 2000) (outlining clinical testing expenses for certain drugs for rare diseases or conditions). tions).

${ }^{32}$ See 26 U.S.C.A. $\$ 170$ (West Supp. 2000) (discussing charitable contribu-

${ }^{33}$ See generally Jendi B. Reiter, Citizens or Sinners? - The Economic and Political Inequity of "Sin Taxes" on Tobacco and Alcohol Products, 29 CoLUM. J.L. \& SOC. PROBS. 443 (1996)(arguing against sin taxes due to their paternalistic nature and the fact that they are economically regressive and discriminatory).

${ }^{34}$ See 26 U.S.C.A. $\$ 5701$ (West Supp. 2000) (tobacco tax).

${ }^{35}$ See 26 U.S.C.A. $\$ 5051$ (West Supp. 2000) (regulating tax on beer); 26 U.S.C.A. $\$ 5001$ (West Supp. 2000) (regulating tax on distilled spirits); 26 U.S.C.A. $\S 5041$ (West Supp. 2000) (regulating tax on wine).

${ }^{36}$ See 26 U.S.C.A. $\$ 5821$ (West 1989) (firearm making tax).

${ }^{37}$ See 26 U.S.C.A. $\$ 4401$ (West 1989) (taxes on wagering).

${ }^{38}$ See 26 U.S.C.A. $\$ 4081$ (West Supp. 2000) (federal gasoline tax).

${ }^{39}$ See 26 U.S.C.A. $\$ 4681$ (West Supp. 2000) (ozone-depleting chemical tax).

${ }^{40}$ See, e.g., United States v. Constantine, 296 U.S. 287, 295 (1935) (holding federal tax punishing liquor dealers who violate state liquor laws unconstitutional); Child Labor Tax Case (Bailey v. Drexel Furniture Co.), 259 U.S. 20, 37 (1922) (holding that federal tax imposed on violators of federal child labor regulations has a "prohibitory and regulatory effect and purpose [that is] palpable"). 
example, the Court has upheld federal taxes on firearms, capable of being concealed, and on persons who "deal in" or prescribe marijuana, stating that a "tax does not cease to be valid because it regulates, discourages, or even definitely deters the activities taxed." 41

The power to tax, then, is the power to govern. Taxes amass the resources necessary for public health services, and provide an effective regulatory mechanism for controlling individual and corporate behavior. Tax incentives and disincentives are powerful tools for promoting or discouraging anything legislators deem important for the health and well-being of the population.

\section{The Power to Spend Is the Power to Allocate Resources and to Induce State Conformance with Federal Public Health Standards}

The powers to tax and spend both are found in the same constitutional phrase of Article I, section eight: "Congress shall have Power To lay and collect Taxes ... to pay the Debts and provide for the common Defence and general Welfare of the United States." The spending power provides Congress with independent authority to allocate resources for the public good; Congress need not justify its spending by reference to a specific enumerated power. ${ }^{42}$ Closely connected to the power to tax, the spending power has two related purposes. First, it authorizes expenditures expressly for the public's health, safety, and wellbeing. Secondly, it effectively induces state conformance with federal regulatory standards.

The power to spend is expressly to promote "general welfare," that is, all reasonable public health purposes. Theoretically, the spending power may be exercised only to pursue a common benefit, as distinguished from a local purpose. Yet, it is Congress that determines whether expenditures are for the common benefit, and the Supreme Court has historically concurred. "Nor is the concept of the general welfare static. Needs

${ }^{41}$ United States v. Sanchez, 340 U.S. 42, 44 (1950) (upholding federal tax on distribution or prescription of marijuana) (citing Sonzinsky v. United States, 300 U.S. 506, 513-14 (1937)(upholding federal tax on firearms capable of concealment)).

${ }^{42}$ See United States v. Butler, 297 U.S. 1, 66 (1936) (holding that Congress' power to tax is expressly conferred by the General Welfare Clause of the Constitution). 
that were narrow or parochial a century ago may be interwoven in our day with the well-being of the Nation." 43 Laurence Tribe believes that such judicial deference is understandable "in an era lacking any coherent theory of the public good as more than an aggregate of private needs and wants." 44 Nonetheless, the Court is not well placed to adopt any particular theory of governmental appropriation, or any other inherently political function.

The spending power does not simply grant Congress the authority to allocate resources; it is also an indirect regulatory device. Congress may prescribe the terms upon which it disburses federal money to the states. The conditional spending power is akin to "a contract: in return for federal funds, the States agree to comply with federally imposed conditions.",45 The Supreme Court permits conditional appropriations, provided the conditions are clearly expressed in the statute ${ }^{46}$ and a reasonable relationship exists between the condition imposed and the program's purposes. ${ }^{47}$ If Congress wants states to conform to federally imposed standards to receive federal funds, it must say so clearly enough to permit the states to make an informed choice. Moreover, states must be cognizant of the consequences in advance of their participation in a federal grant program. $^{48}$

The strings attached to federal resources must also bear some reasonable relationship to the purposes of the grant, and conditional spending cannot be so coercive as to pass the point at which "pressure turns into compulsion." 49 Despite these theoed. 1988).

${ }^{43}$ Helvering v. Davis, 301 U.S. 619, 641 (1937).

${ }^{4}$ Laurence H. Tribe, American Constrtutional Law $\S 5-10$, at 323 (2d

${ }^{45}$ Pennhurst State Sch. \& Hosp. v. Halderman, 451 U.S. 1, 17 (1981).

${ }^{46} \mathrm{See}$ id. (requiring clarity in statutory conditions regarding federal funding).

${ }^{47}$ See South Dakota v. Dole, 483 U.S. 203, 211 (1987) (holding indirect federal spending conditions designed to obtain uniformity in states' drinking age are valid).

${ }^{48}$ See Pennhurst State Sch. \& Hosp., 451 U.S. at 17 (holding conditions for receiving federal funding proper only if states are aware of their terms); see also California v. United States, 104 F.3d 1086 (9th Cir. 1997); West Virginia v. U.S. Dep't of Health \& Hum. Serv., 132 F. Supp. 2d 437 (D. W. Va. 2001).

${ }^{49}$ Steward Mach. Co. v. Davis, 301 U.S. 548, 590 (1937). The judiciary's permissive approach to conditional spending, however, is currently being reexamined. A federal district court in Westside Mothers v. Haveman, 133 F. Supp. 2d 549 (E.D. Mich. 2001), held that third party beneficiaries could not sue the State of Michigan for its alleged nonconformance with the terms of the Medicaid statute. The 
retical limits, the Supreme Court has granted Congress leeway, and has often searched for permissible relationships between the appropriation and the conditions. For example, the Court saw a direct relationship between the appropriation of highway funds and the states' acceptance of a 21-year-old drinking age. Since a major purpose of highway funds is traffic safety, the drinking age limits were deemed constitutionally acceptable. ${ }^{50}$

Congress' power to set the terms upon which state appropriations shall be distributed is an effective regulatory device. States and localities can seldom afford to decline public health grants. ${ }^{51}$ Congress and the federal agencies use conditional appropriations to induce states to conform to federal standards in numerous public health contexts. Federal funding programs for HIV/AIDS, for example, require involuntary post-conviction testing of sex offenders, ${ }^{52}$ adoption of CDC guidelines (or their "equivalent") for preventing transmission of infection during invasive medical procedures, ${ }^{53}$ acceptance of CDC guidelines for counseling and testing of pregnant women, ${ }^{54}$ and compliance

court found that the Medicaid program does not operate to waive Michigan's sovereign immunity. Further, Congress did not unambiguously condition its Medicaid funding contract with Michigan upon the State's consenting to be sued by Medicaid beneficiaries. The court similarly found that the Ex Parte Young (209 U.S. 123 (1908)) doctrine is inapplicable because, inter alia, spending power programs are not the supreme law of the land and the State (as opposed to an officer of the State) is the real party in interest when its officers act within their lawful authority. See also Jim C. v. United States, 235 F.3d 1079 (8th Cir. 2000).

${ }^{50}$ See Dole, 483 U.S. at 211-12 (1987).

51 See Albert J. Rosenthal, Conditional Federal Spending and the Constitution, 39 STAN. L. REV. 1103, 1104 (1987) (noting that states have become increasingly dependent upon federal grants).

${ }^{52}$ See 42 U.S.C.A. § 3756(f) (West 1998); see also Lawrence O. Gostin et al., HIV Testing, Counseling, and Prophylaxis After Sexual Assault, 271 JAMA 1436, 1439 (1994).

53 See Treasury, Postal Service and General Government Appropriations Act, 1992, Pub. L. No. 102-141, Title VI § 633, 1991 U.S.C.C.A.N. (105 Stat.) 834, 87677 , reprinted in, note to 42 U.S.C.A. $\$ 300 \mathrm{ee}-2$ (1994) (requiring states to adopt the CDC's or similar guidelines for preventing infectious disease transmission during invasive procedures); see also Larry Gostin, The HIV-Infected Health Care Professional: Public Policy, Discrimination and Patient Safety, 151 ARCHIVES INTERNAL MED. 663 (1991) (proposing questions for consideration in the debate over restrictions on the practice of HIV-infected health care professionals).

54 Ryan White Care Act Amendments, Pub. L. No. 104-146, § 7, 1996 U.S.C.C.A.N. (110 Stat.) 1369 (codified at 42 U.S.C. \$ 300ff-33). 
with specific community planning and program priorities. ${ }^{55}$ Conditional spending induces states to conform to federal regulatory requirements in other areas as well: eligibility and quality standards relating to Medicare and Medicaid ${ }^{56}$ prohibition on family planning fund recipients from engaging in abortion counseling, referral, and activities advocating abortion as a method of family planning; ${ }^{57}$ and state and local planning for land use and solid waste management. ${ }^{58}$

It is obvious from this discussion that the power to tax and spend is not value neutral, but rather laden with political overtones. Collection of revenues and allocation of resources go to the very heart of the political process. Legislators, as influenced by the public and interest groups, purport to promote the public health, safety, and security. Many of their economic decisions do promote the common good such as taxes on cigarettes and expenditures for anti-smoking campaigns. But their vision is also influenced by moral, cultural, and social values so that government's economic power may be used to discourage abortions, fetal research, sex education, or needle exchange. The power to tax and spend, then, may be used to impede, as well as to promote, legitimate public health goals.

55 See Ronald O. Valdiserri et al., Determining Allocations for HIVPrevention Interventions: Assessing a Change in Federal Funding Policy, 12 AIDS \& PUB. POL'Y J. 138 (1997).

${ }^{56}$ See 42 U.S.C.A. § 1396a (West Supp. 2000) (outlining Medicaid requirements for establishment of State plans); see also 42 U.S.C.A. \$ 1395i-4 (West Supp. 2000) (requiring Medicare grants to states for creating rural health care networks based on statutorily defined eligibility).

${ }^{57}$ See Rust v. Sullivan, 500 U.S. 173 (1991) (permitting federal regulations prohibiting use of Title $\mathrm{X}$ funds in programs where abortion is used as a means of family planning).

${ }_{58}$ See Coastal Zone Management Act of 1972, 16 U.S.C. § 1451-65 (1994) (stating regulatory requirements for the management of coastal lands to preserve, protect, and enhance the Nation's coastal zones); Federal Water Pollution Control Act, 33 U.S.C.A. $\$ \S 1251-1387$ (West 1994 \& Supp. 2000); Resource Conservation and Recovery Act, 42 U.S.C. $\$ 6901$ (1994) (establishing methods and guidelines for solid waste management). 


\section{The Power to Control the Stream of Interstate}

Commerce Is the Power to Regulate Throughout the Public Health Spectrum

The commerce clause, more than any other enumerated power, affords Congress potent regulatory authority. ${ }^{59}$ Article I, section eight states that "[t]he Congress shall have the power... To regulate Commerce with foreign Nations, and among the several States, and with the Indian Tribes." The Supreme Court's expansive construction of the commerce clause, since Franklin Delano Roosevelt's New Deal, facilitated a marked increase in federal regulatory authority in public health matters.

On its face, the commerce clause is limited to controlling the flow of goods and services across state lines. Yet, as interstate commerce has become ubiquitous, activities once considered purely local have come to have national effects, and have, accordingly, come within Congress' commerce power. ${ }^{60}$ The Court's post-1937 construction of "commerce among the states" has been broad; the commerce power has been described by the judiciary as "plenary" or all- embracing, ${ }^{61}$ and has been exerted to affect virtually every aspect of social life. ${ }^{62}$

The broad interpretation of the commerce clause has enabled national authorities to reach deeply into traditional realms of state public health power, and has significantly diminished

${ }^{59}$ Sometimes the federal government acts under a model known as "cooperative federalism." Under this model, federal agencies (e.g., EPA) establish minimum national standards, and states retain the choice to administer the federal standards themselves or have federal authorities implement national standards. This model is found in federal public health statutes concerning water quality (Arkansas v. Oklahoma, 503 U.S. 91, 101 (1992)), occupational health and safety (Gade v. National Solid Wastes Management Ass'n, 505 U.S. 88, 97 (1992)), and conservation (United States Dep't of Energy v. Ohio, 503 U.S. 607, 611-12 (1992); Kenaitze Indian Tribe v. Alaska, 860 F.2d 312 (9th Cir. 1989) (holding state's definition of "rural area" was in conflict with the federal Alaska National Interest Lands Conservation Act)).

${ }^{60}$ See New York v. United States, 505 U.S. 144, 158-59 (1992) (stating that Congress' ability to regulate under the Commerce and Spending Clauses are guided by the Constitution's Necessary and Proper Clause).

${ }^{61}$ See NLRB v. Jones \& Laughlin Steel Corp., 301 U.S. 1, 37 (1937) (describing the vast scope of the commerce power).

${ }_{62}$ See United States v. Darby, 312 U.S. 100, 114 (1941) (stating that Congress is free to regulate articles of commerce whose use may be harmful to public health, morals, and welfare, even if the states do not opt to regulate such use). 
the force of the Tenth Amendment. ${ }^{63}$ The courts have upheld exercises of the commerce clause in the fields of environmental protection, ${ }^{64}$ food and drug safety, ${ }^{65}$ and other public health matters. ${ }^{66}$ In Hodel v. Virginia Surface Mining \& Reclamation Association, Inc., for example, the Supreme Court sustained federal regulation of surface mining, even though regulation of land use is a traditional state function. Congress' intent was to prevent "hazards dangerous to life," such as soil erosion and water pollution, and to "conserve soil, water, and other natural resources."67

The Rehnquist Court has begun to rethink the commerce clause as part of its agenda of gradually returning power from the federal government to the states. In the process, the Court has held that Congress lacks the power to engage in social and public health regulation in areas that lack a substantial impact on interstate commerce (see "new federalism" below).

${ }^{63}$ The commerce clause, in addition to affording Congress considerable police power authority, implicitly limits the states' public health power. The dormant commerce clause limits state authority to regulate in ways that place an undue burden on interstate commerce. Thus, even if Congress has not entered a field of public health, states may not regulate if doing so obstructs commerce among the states. The Supreme Court has a history of invalidating state public health legislation on dormant commerce clause grounds. See, e.g., West Lynn Creamery, Inc. v. Healy, 512 U.S. 186 (1994) (holding milk pricing orders unconstitutional because they violated interstate commerce); Bacchus Imports, Ltd. v. Dias, 468 U.S. 263 (1984) (holding that states cannot exercise their police power to discriminately tax products of other states, such as wholesale liquor taxes, to give local products a favorable advantage); Sporhase v. Nebraska ex rel. Douglas, 458 U.S. 941, 958-60 (1981) (invalidating state public health statute pertaining to ground water use); Chemical Waste Management v. Hunt, 504 U.S. 334 (1992) (finding state act regarding hazardous waste disposal to violate the Commerce Clause).

${ }^{64}$ See New York, 505 U.S. at 159-61 (upholding monetary and access incentive, but invalidating commandeering provisions of the Low-Level Radioactive Waste Policy Act).

${ }^{65}$ See United States v. Sullivan, 332 U.S. 689 (1948) (upholding Congress' commerce clause power to regulate the labeling of medicine that has completed an interstate shipment and is being held for future sales in purely local or intrastate commerce); see also McDermott v. Wisconsin, 228 U.S. 115 (1913) (upholding the Pure Food and Drugs Act of 1906 as a valid exercise of the commerce clause against a challenge based on state legislation).

${ }^{66}$ See, e.g., Hillsborough County, Fla. v. Automated Med. Labs., 471 U.S. 707 (1985) (holding that Hillsborough County ordinances and implementing regulations related to the collection of blood plasma from donors are not pre-empted by FDA blood plasma regulations). (1981).

${ }^{67}$ Hodel v. Virginia Surface Mining \& Reclamation Ass'n, 452 U.S. 264, 277 


\title{
B. State Power to Regulate for the Health, Safety, and Morals of the Community
}

\begin{abstract}
OF OFFENCES AGAINST THE PUBLIC HEALTH, AND THE PUBLIC POLICE OR ECONOMY. [A] species of offences, more especially affecting the commonwealth, are such as are against the public health of the nation; a concern of the highest importance. . . . By the public police and œconomy I mean the due regulation and domestic order of the kingdom: whereby individuals of the state, like members of a well-governed family, are bound to conform their general behaviour to the rules of propriety, good neighbourhood, and good manners; and to be decent, industrious, and inoffensive in their respective stations.
\end{abstract}

William Blackstone $(1769)^{68}$.

Despite a contemporary federal presence, the states since the founding of the republic, have had the predominant public responsibility for population-based health services. Even today, the states account for the majority of traditional public health spending. Early public health law employed a legal maxim that symbolized the intrinsic purposes of a sovereign government: Salus populi est suprema lex: the welfare of the people is the supreme law. ${ }^{69}$ Salus populi demonstrates the close connection between state power and historic understandings of the public's well-being.

The "police power" is the most famous expression of the natural authority of sovereign governments to regulate private interests for the public good. I define police power as:

The inherent authority of the state (and, through delegation, local government) to enact laws and promulgate

684 WILLIAM BLACKSTONE, COMMENTARIES ON THE LAWS OF ENGLAND 16162 (Garland Publishing, Inc. 1978) (1769).

${ }^{69}$ An early treatise on public health law posted the maxim on its cover page. Leroy Parker \& Robert H. Worthington, The LAW OF Public Health and SAFETY, AND THE POWERS AND DUTIES OF BOARDS OF HEALTH (1892). Salus populi was often used by the courts to uphold police regulations during the nineteenth century. See William J. Novak, Public Economy and the Well-ordered Market: Law and Economic Regulation in 19th-Century America, 18 L. \& SOC. INQUIRY 1, 7 n.18 (1993). 
regulations to protect, preserve, and promote the health, safety, morals, and general welfare of the people. To achieve these communal benefits, the state retains the power to restrict, within federal and state constitutional limits, private interests - personal interests in autonomy, privacy, association, and liberty as well as economic interests in freedom to contract and uses of property. ${ }^{70}$

The linguistic and historical origins of the concept of "police" demonstrate a close association between government and civilization: politia (the state), polis (city), and politeia (citizenship). "Police" traditionally connoted social organization, civil authority, or formation of a political community, the control and regulation of affairs affecting the general order and welfare of society. ${ }^{72}$ Such was the context in which Hamilton used the term in the Federalist Papers, to suggest civil peace and public law. ${ }^{73}$ "Police" was meant to describe those powers that permitted sovereign government to control its citizens, particularly for the purpose of promoting the general comfort, health, morals, safety, or prosperity of the public. ${ }^{74}$ The word had a secondary usage as well: the cleansing or keeping clean. This use resonates with early twentieth century public health connotations of hygiene and sanitation.

The police power represents the state's authority to further the goal of all government, to promote the general welfare of society. ${ }^{75}$ States possess the police power as an innate attribute of sovereignty. As sovereign governments before the formation of the United States, the states still retain sovereignty except as (2000)

${ }^{70}$ Lawrence O. Gostin, Public Health Law: Power, Duty, Restraint 48

${ }^{71}$ See WEBSTER'S THIRD NEW INTERNATIONAL DICTIONARY OF THE ENGLISH LANGUAGE, UNABRIDGED 1753 (1986).

${ }^{72}$ See 12 THE OXFORD ENGLISH DictionaRY 22-25 (2d ed. 1989).

${ }^{73}$ THE FEDERALIST Nos. 17, 34 (Alexander Hamilton), quoted in Wendy $\mathrm{E}$. Parmet, From Slaughter-House to Lochner: The Rise and Fall of the Constitutionalization of Public Health, 40 AM. J. LEGAL HIST. 476, 478 (1996) (discussing the origin of the meaning of "police" in the context of the police power).

${ }^{74}$ See Pasquale Pasquino, Theatrum Politicum: The Genealogy of CapitalPolice and the State of Prosperity, in THE Foucault EFFECT: STUdES IN GovERNMENTALITY 105, 108-11 (Graham Burchell et al. eds., 1991) (discussing "police" as "the science of happiness" and the "science of government").

75 See Ruth Locke Roetringer, The Supreme Court and State Police POWER: A STUdY IN FEDERALISM 10-22 (1957) (cataloguing Supreme Court statements on police power). 
surrendered under the Constitution. ${ }^{76}$ Part of the constitutional compact of our Union was that states would remain free to govern within the traditional sphere of health, safety, and morals. All states, to a greater or lesser degree, delegate police powers to local government: counties, parishes, municipalities, or villages. ${ }^{77}$

The definition of "police power" encompasses three principal characteristics: the governmental purpose is to promote the public good; the state authority to act permits the restriction of private interests; and the scope of state powers is pervasive. States exercise police powers to ensure that communities live in safety and security, in conditions conducive to good health, with moral standards, and, generally speaking, without unreasonable interference with human well-being. Police powers legitimize state action to protect and promote broadly defined social goods.

Government, in order to achieve the common good, is empowered to enact legislation, regulate, and adjudicate in ways that necessarily limit, or even eliminate, private interests. Thus, government has inherent power to interfere with personal interests in autonomy, privacy, association, and liberty as well as economic interests in ownership, uses of private property, and freedom to contract. State power to restrict private rights is embodied in the common law maxim sic utere tuo ut alienum non laedas: use your own property in such a manner as not to injure that of another." The maxim supports the police power, giving government authority to determine safe uses of private property to diminish risks of injury and ill-health to others. ${ }^{78}$ More generally, the police power affords government the authority to keep society free from noxious exercises of private rights. The state retains discretion to determine what is considered injurious or unhealthful and the manner in which to regulate, consistent with constitutional protections of personal interests.

\footnotetext{
${ }^{76}$ See Gibbons v. Ogden, 22 U.S. (9 Wheat.) 1 (1824) (establishing the extent of state sovereignty under the commerce clause).

77 See Frank P. GRad, Public Health Law Manual: A Handbook on the LEgal ASPECTS OF PUBlic HEALTH ADMinistration AND ENFORCEMENT 10-15 (2d ed. 1970) (discussing the use of administrative agencies to enforce the state's police powers).

${ }^{78}$ See Commonwealth v. Alger, 61 Mass. (7 Cush.) 53, 96 (1851) (holding that the state legislature has the power to regulate use of private property).
} 
Police powers are so pervasive that they defy orderly or systematic description. The police power evokes images of an organized civil force for maintaining order, preventing and detecting crime, and enforcing criminal laws. But the origins of "police" are deeper and far more textured than notions of basic law enforcement and crime prevention. The police power in early American life, according to Novak, was part of a wellregulated society, a "science and mode of governance where the polity assumed control over, and became implicated in, the basic conduct of social life." After reviewing the expansive early regulation under police jurisdiction (e.g., religion, manners, health, public tranquility and safety, transportation, labor, commerce, and trade), Novak concludes: "No aspect of human intercourse remained outside the purview of police science." 80

Countless judicial opinions and treatises articulate the police powers as a deep well of public authority granted to the body politic. ${ }^{81}$ In Gibbons v. Ogden, Chief Justice Marshall conceived of police powers as an "immense mass of legislation, which embraces every thing within the territory of a State, not surrendered to the general government. ... Inspection laws, quarantine laws, health laws of every description . . . are component parts of this mass." 82

Police powers in the context of public health include all law and regulation directly or indirectly intended to improve morbidity and mortality in the population. The police powers have enabled states and their subsidiary municipal corporations to promote and preserve the public health in areas ranging from injury and disease prevention ${ }^{83}$ to sanitation, waste disposal, and water and air protections. ${ }^{84}$ Police powers exercised by the states include vaccination, ${ }^{85}$ isolation and quarantine, ${ }^{86}$ inspec-

79 William J. Novak, The People's Welfare: LAW and Regulation IN NINETEENTH-CENTURY AMERICA 14 (1996).

${ }^{80} \mathrm{Id}$.

81 See, e.g., ERnSt Freund, The Police Power: Public Policy AND Constitutional Rights (1904); W.P. Prentice, Police Powers ARising Under THE LAW OF OVERRULING NECESSITY 38-41 (Fred B. Rothman \& Co. 1993) (1894).

${ }^{82}$ Gibbons v. Ogden, 22 U.S. (9 Wheat.) 1, 203 (1824).

${ }^{83}$ See Tom Christoffel \& Stephen P. Teret, Protecting the Public: LEGAL ISSUES IN INJURY PREVENTION 25-31 (1993).

${ }^{84}$ See 39 AM. JUR.2D Health $\$ \$ 49-56$ (1999) (indicating that health authorities may establish rules and regulations to preserve health) (state citations omitted).

${ }^{85}$ See Zucht v. King, 260 U.S. 174 (1922) (holding that a municipality may constitutionally vest in its officials broad discretion in matters regarding the enforcement of health law, specifically vaccinations). 
tion of commercial and residential premises, ${ }^{87}$ abatement of unsanitary conditions or other health nuisances ${ }^{88}$ regulation of air and surface water contaminants as well as restriction on the public's access to polluted areas, ${ }^{89}$ standards for pure food and drinking water, ${ }^{90}$ extermination of vermin, ${ }^{91}$ fluoridation of municipal water supplies, ${ }^{92}$ and licensure of physicians and other health care professionals. ${ }^{93}$

The courts have often used the police power as a rough sorting device to separate authority rightfully retained by the states, and those appropriately exercised by the federal government. If the authority exercised was traditionally part of the corpus of police powers, states, at least presumptively, were thought to have a valid claim of jurisdiction. Although the extent of permissible state public health regulation has not been easy to measure, a state's power is "never greater than in matters traditionally of local concern" to the health and safety of its

${ }^{86}$ See generally Leisy v. Hardin, 135 U.S. 100 (1890) (upholding state confiscation of alcohol).

${ }^{87}$ See Givner v. State, 124 A.2d 764, 774 (Md. 1956) (describing extent to which police powers can be exercised on private property for public health and safety); see also See v. City of Seattle, 387 U.S. 541, 550-52 (1967) (Clark, J., dissenting) (listing historical examples of state inspection).

${ }^{88}$ See Jones v. State (In re Indiana Livestock Sanitary Bd.), 163 N.E.2d 605, 606 (Ind. 1960) (finding that, in the exercise of state police powers, states may take the legislative steps necessary to eliminate nuisances); Francis v. Louisiana State Livestock Sanitary Bd., 184 So. 2d 247, 253 (La. Ct. App. 1966) (upholding statute giving State Livestock Sanitary Board plenary power to deal with contagious and infectious diseases of animals).

${ }^{89} \mathrm{See}$ State ex rel. Corp. Comm'n v. Texas County Irrigation \& Water Resources Ass'n, 818 P.2d 449 (Okla. 1991) (upholding state's police power to protect fresh groundwater from pollution).

${ }^{90}$ See Strandwitz v. Ohio Bd. of Dietetics, 614 N.E.2d 817, 824 (Ohio Ct. App. 1992) (finding that, in the interest of protecting health and safety of its citizens, a state may, pursuant to its police powers, regulate businesses regarding food and nutrition).

${ }^{91}$ See Finkelstein v. City of Sapulpa, 234 P. 187 (Okla. 1925) (holding ordinance was not arbitrary or wrongful after city declared junkyard a public nuisance).

${ }^{92}$ See Safe Water Ass'n v. City of Fond Du Lac, 516 N.W.2d 13, 15 (Wis. Ct. App. 1994) (upholding city council's adoption of a water fluoridation program as a valid exercise of state police power); Kaul v. Chehalis, 277 P.2d 352, 354 (Wash. 1955) (en banc) (upholding state provisions to control dental caries). See generally Douglas A. Balog, Comment, Fluoridation of Public Water Systems: Valid Exercise of State Police Power or Constitutional Violation?, 14 PACE ENVTL. L. REV. 645 (1997) (arguing fluoridation statutes will fail the strict scrutiny test if challenged before the U.S. Supreme Court).

${ }_{93}$ See State v. Otterholt, 15 N.W.2d 529, 531 (lowa 1944) (upholding state licensing requirements for chiropractors). 
population..$^{94}$ Courts in many contexts, such as the quality standards for meat, ${ }^{95}$ fruits, and vegetables, ${ }^{96}$ have emphasized the legitimacy of state authority. Even in assessing express federal preemption, courts acknowledge that police powers are "primarily, and historically ... matter[s] of local concern."97 Thus, the judiciary adopts a presumption that "the historic police powers of the States [are] not to be superseded by the Federal Act unless that was the clear and manifest purpose of Congress." 98

\section{New Federalism: Public Health in the American Federalist System}

This Nation has long struggled with the problem of attaining the proper balance of powers between the federal government and the states. The problem is particularly acute in matters of public health because both levels of government want to be seen as responding to the electorate's concerns about health and safety. States and localities are closer to the people and understand better threats to their health. Because they are closer to the community, they can adapt prevention strategies to meet the needs of localities. States also are better placed to "experiment" with solutions to complex health problems. By permitting states to act as laboratories for innovative health policies, the federalist system can, in theory, sort out effective from less effective interventions. The federal government, on the other hand, has greater resources and scientific expertise with which to tackle complicated health policy problems. Many public health problems, moreover, transcend state borders such as pollution, in-

${ }^{94}$ Kassel v. Consolidated Freightways Corp., 450 U.S. 662, 670 (1981) (citing Hunt v. Washington Apple Adver. Comm'n, 432 U.S. 333, 350 (1977)) (holding that Iowa law limiting truck length to 60 feet impermissibly burdened interstate commerce).

${ }^{95}$ See The Slaughter-House Cases, 83 U.S. 36, 62 (1873) (holding that regulation of the slaughter of meat "is, in its essential nature, one which has been... in the constitutional history of this country, always conceded to belong to the States").

${ }^{96}$ See Pacific States Box \& Basket Co. v. White, 296 U.S. 176, 181 (1935), aff' $g$ Pacific States Box \& Basket Co. v. Gehlar, 9 F.Supp. 341 (D. Or. 1934) (holding that food regulation "is part of the inspection laws; [and] was among the earliest exertions of the police power in America").

97 Hillsborough County, Fla. v. Automated Med. Labs., Inc., 471 U.S. 707, 719 (1985) (citing Rice v. Santa Fe Elevator Corp., 331 U.S. 218, 230 (1947)).

${ }_{98}$ Rice v. Santa Fe Elevator Corp., 331 U.S. 218, 230 (1947), quoted in Medtronic, Inc. v. Lohr, 518 U.S. 470, 485 (1996). 
fectious disease, and traffic hazards. Other public health problems are so worrying or pervasive that they demand a national response (e.g., mass firearm fatalities in schools).

It would be comforting to think that the struggles between federal and state public health authorities have been resolved by force of logic (by systematically determining which level of government is likely to be more effective in reducing health threats). The reality, however, is that this struggle has been fought more on political, than policy, grounds. The Supreme Court, moreover, has dramatically shifted its stance as the ideological composition of the Court has changed.

In the early twentieth century (the so-called Lochner era), the Court carved out a zone of state power that could not be infringed by national authorities. During this era, a politically conservative Court struck down a great deal of social and economic regulation. ${ }^{99}$ Franklin Delano Roosevelt's New Deal ushered in a period in which the Court granted Congress expansive powers. Indeed, from 1937 to 1995, the Supreme Court did not find a single piece of social or economic legislation unconstitutional on the basis that Congress had exceeded its commerce clause authority. ${ }^{100}$

In the most recent manifestation of the federalism debate, the Rehnquist Court has explored the contours of a "new federalism" where states retain a sphere of autonomy in matters of public health. ${ }^{101} \mathrm{~A}$ re-energized conservative majority on the Supreme Court, led by Justices Rehnquist and Scalia, has been actively re-centering the balance between national and state power. ${ }^{102}$ The Rehnquist Court has implemented its interpretation of a states-rights agenda in three ways: limiting federal commerce powers, expanding state reserved powers, and undertaking a sustained defense of state sovereign immunity.

${ }^{99}$ See, e.g., Morehead v. New York ex rel. Tipaldo, 298 U.S. 587 (1936) (invalidating state minimum wage requirements for women as a violation of due process).

100 See ERWin ChemerinsKy, Constitutional LAW: PRINCIPLes aNd POLICIES $\$ 3.3$, at 174 (1997).

${ }^{101}$ See United States v. Lopez, 514 U.S. 549 (1995) (holding that the GunFree School Zones Act of 1990 exceeded the authority of Congress to regulate commerce among the states).

${ }^{102}$ See James G. Hodge, Jr., The Role of New Federalism and Public Health Law, 12 J.L. \& HEALTH 309 (1997-98) (discussing the Supreme Court's adoption of a strong rule against federal invasion of "core state functions"). 


\section{The Commerce Power Revisited}

The Supreme Court's 1995 decision in United States v. Lo$p e z,{ }^{103}$ signaled a change in the Court's view about the balance of federal and state powers in the constitutional design. ${ }^{104}$ In Lopez, the Court held that Congress exceeded its commerce clause authority by making gun possession within a school zone a federal offense. Concluding that possessing a gun within a school zone did not "substantially affect" interstate commerce, the Court declared the statute unconstitutional. Here is a case where the Nation's highest court was prepared to invalidate a politically popular measure thought to be important to the public's safety. The Court did not invalidate this legislation on grounds that regulating guns in school zones was an unimportant aim of government, but only that it was outside the reach of the federal government. States would still be free to legislate in traditional realms of public health, but Lopez left little doubt that the Rehnquist Court would henceforth examine the exercise of federal police power authority.

Lopez probably does not indicate a wholesale retreat from the liberal interpretation of the commerce clause. Certainly, Congress will continue to have wide power to regulate businesses and individuals when they engage in explicitly economic or commercial activity. For example, in 2000 , the Court upheld a federal law that restricts the states' ability to disclose personal information in drivers licenses. Because drivers' information is an article of commerce, the Court found that its sale or release into the interstate stream of business is sufficient to support congressional regulation. ${ }^{105}$

The important question Lopez leaves open is the constitutionality of social and public health regulation of intrastate activity. A wide range of pubic health regulation remains vulnerable to commerce clause attacks. For example, in 2000 the

${ }^{103} 514$ U.S. 549 (1995).

${ }^{104}$ The Rehnquist Court's federalism jurisprudence includes Printz v. United States, 521 U.S. 898 (1997) (holding that the federal government cannot require states to enact federal regulatory programs); Seminole Tribe of Fla. v. Florida, 517 U.S. 44 (1996) (holding Congress could not authorize Indian Tribe to sue the state in dispute over gaming activities); and New York v. United States, 505 U.S. 144 (1992) (showing a previously accepted broad scope of federal regulatory powers).

${ }^{105}$ See Reno v. Condon, 528 U.S. 141 (2000) (holding that the Driver's Protection Privacy Act is a proper exercise of congressional regulation of interstate commerce). 
Court invalidated a civil rights remedy permitting survivors to bring federal lawsuits against perpetrators of sexually motivated crimes of violence. Congress proclaimed that violence impairs women's abilities to work, harms businesses, and increases national health care costs. However, the Court found that gendermotivated crimes of violence are primarily state and local concerns. ${ }^{106}$ Additionally, commerce clause challenges threaten important environmental regulations. ${ }^{107}$ For example, in 2001, the Court held that the Army Corps of Engineers' rule extending the definition of "navigable waters" under the Clean Water Act to include intrastate waters used as a habitat by migratory birds exceeded the authority granted to the Corps under the Clean Water Act. The court implied that Congress did not have the power under the Commerce Clause to regulate these intrastate waters. ${ }^{108}$

\section{Reserved Powers Re-Visited}

In New York v. United States, ${ }^{109}$ the Supreme Court, for only the second time in more than half a century, ${ }^{110}$ struck down a federal statute as violating the Tenth Amendment. Congress had enacted monetary and other incentives to induce states to provide for disposal of radioactive waste generated within their borders. To ensure effective action, if a state was unable to dispose of its own waste, it was required under the statute to "take title" and possession of the waste. The Court invalidated the "take title" provision because the Constitution does not confer upon Congress the ability to "commandeer the legislative processes of the States by directly compelling them to enact and en-

${ }^{106}$ See United States v. Morrison, 120 S. Ct. 1740 (2000); see also Martha Minow, Violence Against Women: A Challenge to the Supreme Court, 341 NEw. ENG. J. MED. 1927 (1999) (noting that matters affecting women have traditionally been left to state regulation).

${ }^{107}$ See United States v. Wilson, 133 F.3d 251, 257 (4th Cir. 1997) (holding that a regulation of the Clean Water Act exceeded congressional commerce clause authority).

${ }^{108}$ See Solid Waste Agency v. U.S. Army Corps of Eng'rs, 531 U.S. 159, 121 S. Ct. 675 (2001) (holding the Clean Water Act does not encompass nonnavigable, isolated, intrastate waters such as an abandoned sand and gravel pit).

${ }^{109} 505$ U.S. 144 (1992).

${ }^{110}$ The only other case in that half century to invalidate a federal statute on Tenth Amendment grounds was later overruled. See National League of Cities v. Usery, 426 U.S. 833 (1976), overruled in Garcia v. San Antonio Metro. Transit Auth., 469 U.S. 528 (1985) (holding that the Fair Labor Standards Act does not violate state sovereignty). 
force a federal regulatory program." According to the Court, although Congress may exercise its legislative authority directly over private persons or businesses, it lacks the power to compel states to regulate according to the federal standards. ${ }^{11}$ Congress, of course, may offer incentives to the states to influence their policy choices, through, for instance, conditional spending or cooperative federalism. In both of these two methods, however, the electorate retains the ultimate authority to decide whether the state will comply. By contrast, where national authorities direct the state to regulate, state officials "bear the brunt of public disapproval, while the federal officials who devised the regulatory program may remain insulated from the electoral ramifications of their decision."

In 1997, the Supreme Court used its reasoning in New York $v$. United States to overturn provisions in the Brady Handgun Violence Prevention Act which directed state and local law enforcement officers to conduct background checks on prospective handgun purchasers. ${ }^{113}$ The New York Court held that state legislatures are not subject to federal direction. In the Brady handgun case, the Court held that federal authorities may not supplant the state executive branch. In this instance, Congress did not require the state to make policy, but only to assist in implementing the federal law. The Court rejected the distinction between "making" law or policy on the one hand and merely enforcing or implementing it on the other hand.

As a result of the New York and Brady handgun cases, the Tenth Amendment has become a vehicle for challenging federal statutes that compel state legislative or administrative action. In an era of "new federalism," a body of public health law may be vulnerable to challenges on Tenth Amendment grounds--for example, environmental regulations that direct states to adopt or enforce a federal regulatory scheme.

111 While Congress may not control the manner in which states regulate private parties, it may regulate the activities of the state itself. For example, the Court upheld a congressional requirement that states may not, under certain circumstances, release personal information contained in drivers licenses. See Reno v. Condon, 528 U.S. 141, 146-48 (2000).

112 New York v. United States, 505 U.S. 144, 169 (1992).

${ }^{113}$ See Printz v. United States, 521 U.S. 898, 923-25 (1997). 


\section{State Sovereign Immunity}

The Eleventh Amendment grants states immunity from certain law suits in federal court without its consent. ${ }^{114}$ Known as sovereign immunity, this doctrine is important to states' autonomy because it limits Congress' power to authorize private law suits against states. ${ }^{115}$ In Seminole Tribe of Florida $v$. Florida, ${ }^{116}$ the Supreme Court held that Congress lacks the power under the commerce clause to abrogate the states' sovereign immunity in federal court. ${ }^{17}$

The Rehnquist Court perceives the states' immunity from suit to be a fundamental precept of sovereignty: "Federalism requires that Congress accord States the respect and dignity due them as residuary sovereigns and joint participants in the $\mathrm{Na}$ tion's governance." 118 The Court finished its 1998-99 term with three decisions that demonstrate its profound commitment to state sovereignty in the national constitutional system. The most far-reaching of the three cases declared for the first time that states cannot be sued, without their consent, by private parties in the state's own courts for violations of federal law. ${ }^{119}$ The other two cases nullified congressional abrogations of state Eleventh Amendment immunity from suits in federal courts for patent infringement ${ }^{120}$ and for product misrepresentation. ${ }^{121}$ In 2000 and 2001, the Court similarly found that the federal gov-

${ }^{114}$ See U.S. CONST. amend XI. "The Judicial power of the United States shall not be construed to extend to any [suit] ... commenced or prosecuted against one of the United States by Citizens of another State, or by Citizens or Subjects of any Foreign State." Id.

${ }^{115}$ In Fitzpatrick v. Bitzer, 427 U.S. 445 (1976), the Supreme Court held that Congress could abrogate the state's sovereign immunity and allow states to be sued directly, pursuant to its enforcement power under the Fourteenth Amendment to remedy discrimination.

${ }^{116} 517$ U.S. 44 (1996) (holding that Congress could not authorize Indian tribe to sue the state in dispute over gaming activities).

117 For a discussion of waiver of sovereign immunity under the spending power, see Westside Mothers v. Haveman, 133 F. Supp. 2d 549 (E.D. Mich. 2001) and Jim C. v. United States, 235 F.3d 1079 (8th Cir. 2000).

${ }^{118}$ Alden v. Maine, 527 U.S. 706, 709 (1999).

${ }^{119}$ See id. at 706-10 (addressing the issue of whether Congress has the power under Article I of the Constitution to abrogate the states' sovereign immunity in the states' courts).

${ }^{120}$ See College Savings Bank v. Florida Prepaid Postsecondary Educ. Expense Bd., 527 U.S. 666 (1999) (holding that Congress did not abrogate State Eleventh Amendment immunity for violations of the Trademark Remedy Clarification Act).

${ }^{121}$ See id. 
ernment could not authorize suits against the states under the Age Discrimination in Employment Act (ADEA) or the Americans with Disabilities Act (ADA). ${ }^{122}$

With these decisions on national commerce powers, state reserved powers, and state sovereign immunity, the Rehnquist Court has been ardently defending traditional states' rights against federal political domination. ${ }^{123}$ But beyond the jurisprudential debate about the most appropriate level of government in a federal system lies an important question about the population's health and safety. If the states do not act effectively or uniformly to reduce health threats such as firearms, cigarettes, or pollution, will the judiciary permit national authorities to exercise a police function? The current conservative political thrust evident in the judiciary may impede the federal government's power to act for the health of the population. ${ }^{124}$ At the same time, an activist court is invalidating social legislation enacted through the democratic process, not to safeguard individual liberty, but to pursue an ideal of governance that is much disputed within the Nation.

\section{CONSTITUTIONAL LIMITS: PERSONAL RIGHTS AND FREEDOMS}

[T] he very existence of government presupposes the right of the sovereign power to prescribe regulations demanded by the general welfare for the common protection of all. This principle inheres in the very nature of the social compact.... This power of government -the power, as expressed by Taney, C.J.,... "inherent in every sovereignty, the power to govern men and things"

${ }^{122}$ See Kimel v. Florida Bd. of Regents, 528 U.S. 62 (2000) (holding ADEA clearly included Congress' intent to abrogate states' Eleventh Amendment immunity from actions brought in federal court by private individuals); Board of Trustees v. Garrett, 531 U.S. 356 (2001) (holding that suits in federal court by state employees to recover money damages due to state's failure to comply with the ADA are barred by the Eleventh Amendment).

${ }^{123}$ See, e.g., Gregory v. Ashcroft, 501 U.S. 452 (1991) (holding that states can determine retirement requirements for judges without violating the Age Discrimination in Employment Act).

124 See Neil A. Lewis, A Court Becomes a Model of Conservative Pursuits, N.Y. TIMES, May 24, 1999, at A1 (stating that the Fourth Circuit Court of Appeals has "quietly but steadily become the boldest conservative court in the nation [issuing] remarkable rulings and... a striking tone"). 
-- is not, however, an uncontrollable or despotic authority, subject to no limitation, exercisable with or without reason, in the discretion or at the whim or caprice of the legislative body.... [The constitutional guaranty] is designed for the protection of personal and private rights against encroachments by the legislative body... as held and understood when the Constitution was adopted.

John A. Andrews (1889) ${ }^{125}$

Personal coercion and economic regulation remain staples of public health practice in America. ${ }^{126}$ Throughout most of the major infectious disease epidemics health officials have resorted to compulsory programs of testing, vaccination, physical examination, treatment, isolation, and quarantine. Government agencies license health care providers, inspect food establishments, regulate food and drugs, set standards for occupational health and safety, control pollutants, and abate nuisances. Even the most cursory examination of public health practice reveals the extensive forms of personal coercion and economic regulation that pervade society. I am not suggesting that coercion and regulation are the preferred strategies for ameliorating health threats. Nevertheless, any careful discussion of public health law must confront the inevitability of governmental exercise of power, as well as the potential trade-offs between personal freedom and the common good.

The question, therefore, arises, What limits exist on government powers to restrict personal and economic interests in the search for a healthy society? That is, under what circumstances may the government interfere with a person's autonomy, privacy, liberty, or property to achieve health benefits for the population as a whole?

${ }^{125}$ People v. Budd, 22 N.E. 670, 672 (N.Y. 1889).

${ }^{126}$ Early public health law texts are dominated by discussions of compulsory powers. See, e.g., LEROY PARKER \& ROBERT H. WORTHINGTON, THE LAW OF PUBLIC HEALTH AND SAFETY, AND THE POWERS AND DUTIES OF BOARDS OF HEALTH at xxxviii (1892). "It needs no argument to prove that the highest welfare of the State is subserved by protecting the life and health of its citizens by laws which will compel the ignorant, the selfish, the careless and the vicious, to so regulate their lives and use their property, as not to be a source of danger to others. If this be so, then the State has the right to enact such laws as shall best accomplish this purpose, even if their effect is to interfere with individual freedom and the untrammeled enjoyment of property." Id. 


\section{A. Early Constitutional Law and the Social Contract}

While the Constitution does not explicitly mention public health, it does recognize the right of states to execute inspection laws which were incident to quarantines. ${ }^{127}$ Chief Justice Marshall, as early as 1824, suggested that states have inherent and pervasive authority to safeguard the public's health. ${ }^{128}$ For more than a century after the Marshall Court, the judiciary remained highly deferential to the exercise of public health powers. ${ }^{129}$ The major impetus for judicial activity in the public health field was the sporadic occurrence of epidemics of leprosy, smallpox, scarlet fever, cholera, venereal disease, and tuberculosis. In this context, private rights were subordinated to the public interest, and individuals were seen as bound to conform their conduct for society's good. As one court put it, police powers do not frustrate personal rights because there is no liberty to harm others. ${ }^{130}$

In early American jurisprudence the judiciary periodically suggested that public health regulation was immune from constitutional review, ${ }^{131}$ expressing the notion that "where the police power is set in motion in its proper sphere, the courts have no jurisdiction to stay the arm of the legislative branch...."132 The core issue, of course, was to understand what was meant by the "proper legislative sphere," for it was never supposed in

${ }^{127}$ See U.S. CoNST. art. I, § 10, cl. 2.

${ }^{128}$ See Gibbons v. Ogden, 22 U.S. (9 Wheat.) 1, 203 (1824).

129 See Deborah Jones Merritt, Communicable Disease and Constitutional Law: Controlling AIDS, 61 N.Y.U. L. REv. 739, 754 (1986) (stating that the courts are rarely sympathetic to constitutional challenges against public health measures); see also Scott Burris, Rationality Review and the Politics of Public Health, 34 VILL. L. REV. 933 (1989) (discussing the "rational medical basis test" as a standard of review in public health matters involving individual constitutional rights).

${ }^{130}$ See Kirk v. Wyman, 65 S.E. 387,389 (S.C. 1909) (stating that statutes and ordinances which require isolation of people infected with contagious diseases for the purpose of protecting public health do not violate the constitutional guarantees of liberty).

131 See PARKER \& WorTHINGTON, supra note 126, at 5 (stating that "the legislature has a discretion which will not be reviewed by the courts; for it is not a part of the judicial functions to criticise the propriety of legislative action in matters which are within the authority of the legislative body").

${ }^{132}$ State ex rel. Conway v. Southern Pac. Co., 145 P.2d 530, 532 (Ariz. 1943) (quoting State ex rel. McBride v. Superior Court, 174 P. 973, 976 (Wash. 1918)). 
American constitutional history that government could act in an arbitrary manner free from judicial control. ${ }^{133}$

The 1905 case of Jacobson v. Massachusetts ${ }^{134}$ made clear that the state has an extensive power to coerce for the public well-being, but that its powers are limited. Henning Jacobson was fined for his refusal to comply with a Cambridge ordinance requiring smallpox vaccination. Jacobson's legal brief asserted that "a compulsory vaccination law is unreasonable, arbitrary and oppressive, and, therefore, hostile to the inherent right of every freeman to care for his own body and health in such way as to him seems best." ${ }^{, 135}$ His was a classic claim in favor of a laissez-faire society and the natural rights of persons to bodily integrity and decisional privacy.

The Supreme Court preferred a more community-oriented philosophy where citizens have duties to one another and to the society as a whole. Justice Harlan conveyed this sense of community:

[T] he liberty secured by the Constitution of the United States ... does not import an absolute right in each person to be, at all times and in all circumstances, wholly freed from restraint. There are manifold restraints to which every person is necessarily subject for the common good. On any other basis organized society could not exist with safety to its members. Society based on the rule that each one is a law unto himself would soon be confronted with disorder and anarchy. Real liberty for all could not exist under the operation of a principle which recognizes the right of each individual person to use his own, whether in respect of his person or his

${ }^{133}$ Pre-Jacobson understandings of constitutional restraints recognized that "a statute, to be upheld as a valid exercise of the police power, must have some relation to those ends; the rights of citizens may not be invaded under the guise of police regulation. ..." PARKER \& WORTHINGTON, supra note 126, at 6. See also Mugler v. Kansas, 123 U.S. 623, 661 (1887) (upholding prohibition on sale of alcoholic beverages, but emphasizing the duty of the courts to adjudge whether a statute has a "real or substantial relation" to public health); Brimmer v. Rebman, 138 U.S. 78 (1891) (invalidating state prohibition on sale of meat because of overbroad prevention on the sale of wholesome, fresh meat) (aff' $g$ In re Rebman, (E.D. Va. 1890)).

134197 U.S. 11 (1905).

135 Jacobson, 197 U.S. at 26. 
property, regardless of the injury that may be done to others. ${ }^{136}$

The Court's opinion is filled with examples ranging from sanitary laws and animal control to quarantine, demonstrating the breadth of valid police powers. The legacy of Jacobson surely is its defense of social welfare philosophy and unstinting support of police power regulation. ${ }^{137}$ Beyond its passive acceptance of state legislative discretion in matters of public health, however, was the Court's first systematic statement of the constitutional limitations imposed on government. The Jacobson court established a floor of constitutional protection. Public health powers are constitutionally permissible only if they are exercised in conformity with four standards that I shall call public health necessity, reasonable means, proportionality, and harm avoidance. These standards, while permissive of public health intervention, nevertheless require a deliberative governmental process to safeguard autonomy.

Public Health Necessity. Public health powers are exercised under the theory that they are necessary to prevent an avoidable harm. Justice Harlan, in Jacobson, insisted that police powers must be based on the "necessity of the case" and could not be exercised in "an arbitrary, unreasonable manner" or go "beyond what was reasonably required for the safety of the public."138 Early meanings of the term "necessity" are consistent with the exercise of police powers: to necessitate was to "force" or "compel" a person to do that which he would prefer not to do, and the "necessaries" were those things without which life could not be maintained. ${ }^{139}$ Government, in order to justify the use of compulsion, therefore, must act only in the face of a demonstrable health threat. ${ }^{140}$

${ }^{136}$ Id. (citing Commonwealth v. Alger, 7 Cush. 53, 84 (Mass. 1851)).

${ }^{137}$ Ironically, the Court during that era is best known for its libertarian position on questions of economic rights, see the discussion of economic due process and the Lochner case later in this article. See discussion infra pp. 312-14.

${ }^{138}$ Jacobson, 197 U.S. at 28.

139 See 7 THE OXFORD ENGLISH DictionARY 60-63 (1933).

${ }^{140}$ Even though, under Jacobson, the government is permitted to act only in the face of a demonstrable threat to health, the Coust did not appear to require the state to produce credible scientific, epidemiologic, or medical evidence of that threat. Justice Harlan said that "what the people believe is for the common welfare must be accepted as tending to promote the common welfare, whether it does in fact or not." Jacobson, 197 U.S. at 35 (quoting Viemeister v. White, 72 N.E. 97, 99 (N.Y. 1904)). 
The standard of public health necessity requires, at a minimum, that the subject of the compulsory intervention must actually pose a threat to the community. In the context of infectious diseases, for example, public health authorities could not impose personal control measures (e.g., mandatory physical examination, treatment, or isolation) unless the person was actually contagious or, at least, there was reasonable suspicion of contagion.

Reasonable Means. Under the public health necessity standard, government may act only in response to a demonstrable threat to the community. The methods used, moreover, must be designed to prevent or ameliorate that threat. The Jacobson court adopted a means/ends test that required a reasonable relationship between the public health intervention and the achievement of a legitimate public health objective. Even though the objective of the legislature may be valid and beneficent, the methods adopted must have a "real or substantial relation" to protection of the public health, and cannot be "a plain, palpable invasion of rights." 141

Proportionality. The public health objective may be valid in the sense that there exists a risk to the public, and the means may be reasonably likely to achieve that goal. Yet, a public health regulation is unconstitutional if the human burden imposed is wholly disproportionate to the expected benefit. "[T]he police power of a State," said Justice Harlan, "may be exerted in such circumstances or by regulations so arbitrary and oppressive in particular cases as to justify the interference of the courts to prevent wrong and oppression." 142

Public health authorities have a constitutional responsibility not to over-reach in ways that unnecessarily invade personal spheres of autonomy. This suggests a requirement for a reasonable balance between the public good to be achieved and the degree of personal invasion. If the intervention is gratuitously onerous or unfair it may overstep constitutional boundaries.

Harm Avoidance. Those who pose a risk to the community can be required to submit to compulsory measures for the com-

${ }^{141} I d$. at 31; see also Nebbia v. New York, 291 U.S. 502, 525 (1934) (noting that public welfare regulation must not be "unreasonable, arbitrary or capricious, and that the means selected shall have a real and substantial relation to the object sought to be attained").

${ }^{142}$ Jacobson, 197 U.S. at 38. 
mon good. The control measure itself, however, should not pose a health risk to its subject. Justice Harlan emphasized that Henning Jacobson was a "fit subject" for smallpox vaccination, but asserted that requiring a person to be immunized who would be harmed is "cruel and inhuman in the last degree." 143 If there had been evidence that the vaccination would seriously impair Jacobson's health, he may have prevailed in this historic case. ${ }^{144}$

Jacobson era cases reiterate the theme that public health actions must not harm subjects. For example, a quarantine of a district in San Francisco was held unconstitutional, in part, because it created conditions likely to spread bubonic plague. ${ }^{145}$ Similarly, courts required safe and habitable environments for persons subject to isolation on the theory that public health powers are designed to promote wellbeing, and not to punish the individual. ${ }^{146}$

\section{B. Public Health Powers in the Modern Constitutional Era}

The march toward more rigorous constitutional scrutiny of governmental action has been slow, cyclical, and politically charged. During the two decades beginning in the 1960 s, con-. stitutional doctrine changed markedly. It is important to remember that constitutional law reflects culture, society, and politics. Many cultural developments brought about this revo-

${ }^{143}$ Id. at 39.

144 See id. (stating "[w]e are not to be understood as holding that the statute was intended to be applied to such a case [involving an unfit subject], or, if it was so intended, that the judiciary would not be competent to interfere and protect the health and life of the individual concerned"). It is interesting to note that Henning Jacobson did allege that, when a child, a vaccination had caused him "great and extreme suffering." Id. at 36. Jacobson's claim of potential harm was not without merit. In Jenner's original publication in Inquiry in 1799, he noted in case IV, a severe adverse reaction to vaccination now termed anaphylaxis. See Harry Bloch, Edward Jenner (1749-1823): The History and Effects of Smallpox, Inoculation, and Vaccination, 147 AM. J. DISEASES CHILDREN 772, 774 (1993).

${ }^{145}$ See Jew Ho v. Williamson, 103 F. 10 (C.C.N.D. Cal. 1900). "It must necessarily follow that, if a large ... territory is quarantined, intercommunication of the people within that territory will rather tend to spread the disease than to restrict it." Id. at 22.

${ }^{146}$ See, e.g., Kirk v. Wyman, 65 S.E. 387, 391 (S.C. 1909) (holding that even temporary isolation in a pesthouse would be "a serious affliction and peril to an elderly lady."); Youngberg v. Romeo, 457 U.S. 307, 319 (1982) (holding that to effectuate the constitutional interests in "safety," the state must "provide minimally adequate or reasonable training to ensure safety and freedom from undue restraint"). But see Ex parte Martin, 188 P.2d 287, 291 (Cal. Ct. App. 1948) (upholding isolation of people with sexually transmitted diseases in over-crowded county jail). 
lutionary shift: the civil rights movement for AfricanAmericans, protests against the Vietnam War, and the reemergence of feminism. ${ }^{147}$ Responding to these and other social movements, the Supreme Court, principally under Chief Justice Earl Warren, revitalized and strengthened the Court's position on issues of equality and civil liberties. The Warren Court set a liberal agenda that prized personal freedom and nondiscrimination, and exhibited a healthy suspicion of government.

The Warren Court developed multiple standards of constitutional review, a form of constitutional reasoning still employed by the Supreme Court. It will be helpful to explain the standards used in equal protection analysis and to apply those standards to modern public health policies. It will become evident that even in an era of heightened constitutional scrutiny, the Court continues its permissive approach in most matters of public health.

\section{Minimum Rationality Review}

The Court's lowest, and most commonly used, standard of constitutional review is often called the rational basis test. All public health regulation must, at least, comply with this minimum rationality standard. ${ }^{148}$ Rational basis review requires both a legitimate government objective and means that are reasonably related to attaining that objective. Police power regulation is a classically valid objective: "Public safety, public health, morality, peace and quiet, law and order-these are some of the more conspicuous examples of [legitimate governmental interests]."149 The Court has expressly upheld numerous public health objectives, including traffic safety, ${ }^{150}$ detection of underdiagnosed disease, ${ }^{151}$ and disease prevention. ${ }^{152}$ Not only must

${ }^{147}$ See Thomas B. Stoddard \& Walter Rieman, AIDS and the Rights of the Individual: Toward a More Sophisticated Understanding of Discrimination, 68 MILBANK Q. 143, 146-49 (Supp. I 1990).

${ }^{148}$ For a thoughtful examination of the subject, see Burris, supra note 129.

149 Berman v. Parker, 348 U.S. 26, 32 (1954) (holding that eminent domain statute is within the police power of a state to enforce).

${ }^{150}$ See Railway Express Agency, Inc. v. New York, 336 U.S. 106 (1949) (upholding regulation of vehicle advertising as a traffic safety measure).

${ }^{151}$ See Williamson v. Lee Optical, 348 U.S. 483 (1955) (upholding state law favoring ophthalmologists and optometrists over opticians to ensure proper diagnosis of eye disease). 
the government's purpose be valid, the means adopted must be reasonably directed toward achieving the public health objective. ${ }^{153}$ For example, an ordinance requiring owners of vacant lots to clear-cut all vegetation was invalidated because the town's claim that noxious vines could grow was implausible. ${ }^{154}$

Rationality review is highly permissive of public health regulation, with the Court granting a strong presumption of constitutionality. ${ }^{155}$ Constitutional review "is not a license for courts to judge the wisdom, fairness, or logic of legislative choices."156 The judiciary leaves the desirability of public health regulation to the legislature. Further, the legislature need not "actually articulate at any time the purpose or rationale" for its public health policy. ${ }^{157}$ Rather, public health regulation is upheld if there is "any reasonably conceivable state of facts that could provide a rational basis for the classification." 158

Scientific evidence of risk is the raison d'être of public health action. Yet, under rational basis review, the state is not obliged to produce scientific evidence. ${ }^{159}$ "Legislative choice is not subject to courtroom factfinding and may be based on rational speculation unsupported by evidence or empirical data." 160 Indeed, the courts often defer to expert agencies on matters of public health policy because agencies are faced with

152 See Jacobson v. Massachusetts, 197 U.S. 11 (1905) (upholding state law mandating smallpox vaccinations against Fourteenth Amendment challenge).

${ }^{153}$ See Heller v. Doe, 509 U.S. 312, 321 (1993) (stating courts should "accept a legislature's generalizations even when there is an imperfect fit between means and ends").

${ }^{154}$ See Berger v. City of Mayfield Heights, 154 F.3d 621 (6th Cir. 1998) (holding that ordinance requiring certain lots to be clear cut of all vegetation over eight inches was arbitrary).

${ }^{155}$ See Village of Euclid v. Ambler Realty Co., 272 U.S. 365 (1926). Persons adversely affected by public health regulation carry the burden of proving that the law is "arbitrary and unreasonable, having no substantial relation to the public health, safety, morals, or general welfare." Id. at 395; see also Lehnhausen v. Lake Shore Auto Parts Co., 410 U.S. 356, 364 (1973) (stating that "[t]he burden is on the one attacking the legislative arrangement to negative every conceivable basis which might support it") (quoting Madden v. Kentucky, 309 U.S. 83, 88 (1940)).

${ }^{156}$ FCC v. Beach Communications, Inc., 508 U.S. 307, 313 (1993).

${ }^{157}$ Nordlinger v. Hahn, 505 U.S. 1, 15 (1992) (citing United States R.R. Retirement Bd. v. Fritz, 449 U.S. 166, 179 (1980)).

${ }^{158}$ Beach Communications, Inc., 508 U.S. at 313.

${ }^{159}$ See Heller v. Doe, 509 U.S. 312, 320-21 (1993) (upholding statutes requiring "clear and convincing" evidence to civilly commit mentally retarded, but "beyond a reasonable doubt" to commit mentally ill).

${ }^{160}$ Beach Communications, Inc., 508 U.S. at 307. 
complex practical problems that require "rough accommodations--illogical, it may be, and unscientific."161 The courts, under rationality review, have upheld a wide spectrum of public health regulations ranging from infectious disease screening ${ }^{162}$ and mandatory treatment ${ }^{163}$ to regulation of landfills ${ }^{164}$ and licensing of fishermen. ${ }^{165}$

Rationality review almost always results in a finding that police power regulation is constitutional. Yet, the Supreme Court on several occasions has engaged in more exacting scrutiny of discriminatory government action, while purporting to apply the rational basis test-so-called, "rational basis with a bite."

In City of Cleburne v. Cleburne Living Center, Inc., ${ }^{166}$ the Supreme Court, using rational basis review, declared unconstitutional a zoning ordinance that effectively prevented the operation of a group home for persons with mental retardation. Under conventional rationality review, the judiciary would be deferential, but the Court felt that the legislature was motivated by animosity against a traditionally disenfranchised group. Similarly, in Romer v. Evans, ${ }^{167}$ the Supreme Court saw prejudice against homosexuals, another group that is disadvantaged in the political process. Colorado had amended its state constitution, to prohibit all legislative, executive, or judicial action designed to protect lesbians or gay men from discrimination. The Court held that the state constitutional amendment "fails,

${ }^{161}$ Metropolis Theatre Co. v. City of Chicago, 228 U.S. 61, 69-70 (1913).

${ }^{162}$ See Local 1812, American Fed'n of Gov't Employees v. United States Dep't of State, 662 F. Supp. 50 (D.D.C. 1987) (upholding government's mandatory HIV testing program for foreign service personnel).

${ }_{163}$ See, e.g., Reynolds v. McNichols, 488 F.2d 1378 (10th Cir. 1973) (finding no equal protection violation when plaintiff, a female prostitute, was detained and treated under local ordinance for reasonable suspicion of having a venereal disease, but her "male companions" were not detained).

${ }^{164}$ See Pro-Eco, Inc., v. Board of Comm'rs of Jay County, Ind., 57 F.3d 505 (7th Cir. 1995) (holding that depositing garbage in landfills is not a fundamental right; public health concern is a sufficient reason for regulation).

${ }^{165}$ See New York State Trawlers Ass'n v. Jorling, 16 F.3d 1303 (2d Cir. 1994) (upholding conservation law that prohibited trawlers from possessing lobsters in Long Island Sound).

${ }_{166} 473$ U.S. 432 (1985). But cf. Heller v. Doe, 509 U.S. 312 (1993) (holding that a higher standard of proof is required for involuntary commitment of mentally ill, as opposed to mentally retarded, which requires a rational basis).

${ }^{167} 517$ U.S. 620 (1996). 
indeed defies," the rational basis test. ${ }^{168}$ The State's reason, said the Court, "seems inexplicable by anything but animus toward the class it affects; it lacks a rational relationship to legitimate state interests."169 Both Cleburne and Romer suggest that there may be areas where legislatures act against politically disfavored groups with such hostility that the Court will be prepared to examine legislative motives more carefully than in conventional applications of rationality review.

Rationality review is extraordinarily important in public health because most prevention strategies will be measured against this standard. Since risk assessment and scientific evidence are so important in evaluating public health measures, rationality review hardly seems sufficient. ${ }^{170}$ This lowest standard of review does not force public health authorities to justify their actions by demonstrating a significant risk and that the intervention is likely to ameliorate that risk; nor does it require authorities to explain why they chose to target particularly vulnerable or unpopular groups such as gays, prostitutes, homeless persons, or drug users. Discrimination on the basis of sexual orientation, disability, and socio-economic class has played an important role in the history of public health. The future of rationality review in light of cases such as Cleburne and Romer may well demonstrate whether the Court is prepared to look more carefully at disfavored treatment of politically unpopular groups.

\section{Intermediate Review}

The Supreme Court adopts an intermediate level of review where government discriminates on the basis of $\operatorname{sex}^{171}$ or against "illegitimate" children. ${ }^{172}$ Under this middle level of constitutional review, the state must establish that its classification serves important governmental objectives and must be substan-

${ }^{168} I d$. at 632 .

${ }^{169} \mathrm{Id}$.

${ }^{170}$ See Burris, supra note 129 , at 937-49.

171 See United States v. Virginia, 518 U.S. 515 (1996) (using intermediate scrutiny to invalidate the maintenance of an all-male military college).

${ }^{172}$ See New Jersey Welfare Rights Org. v. Cahill, 411 U.S. 619 (1973) (using intermediate scrutiny to strike down law that limited benefits to families with two individuals of the opposite sex "ceremonially married"). 
tially related to those objectives. ${ }^{173}$ Thus, the government's interest must be "important," not simply legitimate, and the relationship between means and ends must be "substantial," not merely reasonable. The Court exercises great care in examining government policy under this middle tier of review. In invalidating gender discrimination at the Virginia Military Institute (VMI), Justice Ginsberg emphasized that the state "must demonstrate 'an exceedingly persuasive justification'.... The burden of justification is demanding and rests entirely on the State."174

Public health actions that classify on the basis of sex, therefore, are subject to a rigorous form of judicial review. Consider, for example, mandatory syphilis testing of female, but not male, applicants for a marriage license. This sexual classification probably would be unconstitutional, because it does not serve a substantial public health purpose. ${ }^{175}$ The pre-natal HIV testing of women, however, would probably withstand constitutional scrutiny, because the state could demonstrate a substantial reason for focusing the intervention on women.

\section{Strict Scrutiny}

The Supreme Court strictly reviews laws that create "suspect" classifications or burden "fundamental" rights and liberty interests. The Court has decided that race, ${ }^{176}$ national origin, ${ }^{177}$ and, with some exceptions, alienage ${ }^{178}$ are suspect classes. ${ }^{179}$

${ }^{173}$ See Craig v. Boren, 429 U.S. 190, 197 (1976) (stating that gender-based classifications on legal drinking age must serve state interests and be substantially related to achievement of state objectives).

${ }^{174}$ Virginia, 518 U.S. at 531, 533.

175 But see Reynolds v. McNichols, 488 F.2d 1380, 1383 (10th Cir. 1973) (enforcing city's "hold and treat" ordinance requiring testing and treatment of persons reasonably suspected of having an STD against a female sex worker, but not the customer; "the ordinance is aimed at the primary source of venereal disease and the ... [prostitute] was the potential source, not her would-be customer"); People v. Adams, 597 N.E.2d 574 (III. 1992) (holding that mandatory HIV testing of prostitutes does not violate equal protection because it draws no distinction between male and female offenders and no evidence of legislative intent to disadvantage women).

${ }^{176}$ See, e.g., Loving v. Virginia, 388 U.S. 1 (1967) (invalidating Virginia's antimiscegenation law that made it a crime for a white person and a "colored person" to marry).

${ }^{177}$ See, e.g., Korematsu v. United States, 323 U.S. 214 (1944) (applying strict scrutiny to uphold the military curfew for persons of Japanese descent during World War II).

${ }^{178}$ Classifications based on alienage involve discrimination against persons who are not United States citizens. See, e.g., Bernal v. Fainter, 467 U.S. 216 (1984) (invalidating law requiring that a notary public be a U.S. citizen). 
The Court also strictly reviews government actions that burden fundamental rights and liberty interests including procreation, ${ }^{180}$ marriage, ${ }^{181}$ interstate travel ${ }^{182}$ and bodily integrity. ${ }^{183}$

The usual judicial deference to public health regulation should dissolve in cases where the Court adopts a heightened standard of review. Although public health objectives undeniably are "compelling," few governmental policies survive strict scrutiny. The Court is likely to reserve its highest level of scrutiny only for the most discriminatory or intrusive public health powers. Consider a public health intervention that discriminates on the basis of race or gender, such as the kind of public health intervention that was conducted in Jew Ho v. Williamson. ${ }^{184}$ In that case, a quarantine was made to operate exclusively against Chinese Americans, leaving Caucasian Americans free from coercive power. Although Jew Ho was decided in the early twentieth century, it is the kind of discriminatory intervention that would trigger strict scrutiny today.

Interventions that deprive persons of their liberty (e.g., isolation) or bodily integrity (e.g., compulsory treatment) should also trigger heightened scrutiny. The power to detain persons with infectious disease, for example, would be put to a strict legal test. ${ }^{185}$ Civil confinement is a uniquely serious form

179 So-called "positive" discrimination benefiting racial minorities also triggers strict scrutiny. See, e.g., Regents of Univ. of Cal. v. Bakke, 438 U.S. 265 (1978) (invalidating University of California's affirmative action program for medical school admission).

${ }_{180}$ See Skinner v. Oklahoma, 316 U.S. 535 (1942) (striking down statute authorizing the sterilization of habitual criminals).

${ }^{181}$ See, e.g., Loving, 388 U.S. at 11 (invalidating law prohibiting marriage between whites and non-whites).

${ }^{182}$ See Shapiro v. Thompson, 394 U.S. 618 (1969) (invalidating residency requirements for welfare programs).

${ }^{183}$ See Cruzan v. Director, Missouri Dep't of Health, 497 U.S. 261, 278 (1990) (stating " $[t]$ he principle that a competent person has a constitutionally protected liberty interest in refusing unwanted medical treatment may be inferred from our prior decisions"); Washington v. Harper, 494 U.S. 210, 221 (1990) (holding mentally ill prisoner has a "significant liberty interest in avoiding the unwanted administration of antipsychotic drugs").

${ }^{184} 103$ F. 10 (C.C.N.D. Cal. 1900).

185 See State v. Snow, 324 S.W.2d 532, 534 (Ark. 1959) (stating that civil commitment law is not penal, but is to be strictly construed to protect rights of citizens). This section will not discuss segregation of persons with infectious disease in correctional facilities. Rather than using a "strict scrutiny" approach, courts give considerable deference to prison authority decisions to isolate inmates, even where 
of restraint because it constitutes "a massive curtailment of liberty." ${ }^{186}$ Detention is justified not on a finding that a person has committed a criminal offense, but because of a prediction of future dangerousness. Individuals, moreover, are not detained for a finite period based on the seriousness of past behavior. Rather, they are confined indefinitely, particularly if the condition is not susceptible to treatment. Under contemporary constitutional standards, the state has to demonstrate a compelling public health interest; a "well-targeted" intervention; and that there exists no "less restrictive alternative." 187 The state must also provide procedural due process. The following analysis uses civil commitment of the mentally ill as an analogy because, like detention of persons with infectious disease, the intervention is non-punitive and is based on the health and safety of the individual and the community. ${ }^{188}$

A compelling state interest in confinement.-Under the Supreme Court's "strict scrutiny" analysis, the state must have a compelling interest that is substantially furthered by the deten-

the scientific evidence of significant risk appears weak. See, e.g., Onishea v. Hopper, 171 F. 3d 1289 (11th Cir. 1999) (upholding segregation of HIV-infected inmates).

${ }^{186}$ Vitek v. Jones, 445 U.S. 480, 491 (1980) (quoting Humphrey v. Cady, 405 U.S. 504, 509 (1972)); see also Addington v. Texas, 441 U.S. 418, 425 (1979) (recognizing that civil commitment is a "significant deprivation of liberty").

${ }_{187}$ The intrusiveness of the detention should be taken into account in a constitutional analysis: (i) the specific purpose of confinement-e.g., purely preventative or therapeutic; (ii) the duration of confinement-e.g., a short period of curative treatment or an indefinite period of preventive detention; and (iii) the place of confinement-e.g., in a person's home, hospital, or jail. For example, scholars have uniformly rejected isolation of persons with HIV because the confinement would be preventive, indeterminate, and would require specially designated facilities. See Larry Gostin, The Politics of AIDS: Compulsory State Powers, Public Health, and Civil Liberties, 49 OHIO ST. L.J. 1017 (1989) (criticizing the use of coercive state public health powers to prevent the spread of AIDS as discriminatory and not deterring of dangerous health behavior); Kathleen M. Sullivan \& Martha A. Field, AIDS and the Coercive Power of the State, 23 HARV. C.R.-C.L. L. REv. 139 (1988) (discussing potential quarantine approaches for the AIDS epidemic); Wendy E. Parmet, AIDS and Quarantine: The Revival of an Archaic Doctrine, 14 HOFSTRA L. REV. 53 (1985) (discussing the potential use of quarantine regulations for persons with AIDS); Merritt, supra note 129 , at 778 (stating that a compelling state interest must be shown to confine or isolate an individual).

188 See Greene v. Edwards, 263 S.E.2d 661 (W. Va. 1980). “[Mnvoluntary commitment for having communicable tuberculosis impinges upon the right to 'liberty, full and complete liberty' no less than involuntary commitment for being mentally ill...." Id. at 663 (quoting State ex rel. Hawks v. Lazaro, 202 S.E.2d 109, 122 (W. Va. 1974)). 
tion. ${ }^{189}$ Consequently, only persons who are truly dangerous (i.e., pose a significant risk of transmission), can be confined. ${ }^{190}$ In $O^{\prime}$ Connor $v$. Donaldson, ${ }^{191}$ the Supreme Court held that, without providing treatment, the state could not confine a nondangerous mentally ill person who is capable of surviving in the community. Lower courts have gone further by requiring actual danger as a condition of civil confinement in both mental health ${ }^{192}$ and infectious disease ${ }^{193}$ contexts. For example, in In re City of New York v. Doe ${ }^{194}$ the court required clear and convincing evidence of the person's inability to complete a course of TB medication before permitting restraint.

A "well targeted" intervention.-Public health authorities sometimes order the detention of a large group of people-e.g., everyone in a geographic area. If some members of the group would not, in fact, transmit infection, the state action is overbroad. The Supreme Court finds over-inclusive restraints constitutionally impermissible because it deprives individuals of liberty without justification. For example, civil confinement of all homeless persons with tuberculosis on the theory that the

${ }^{189}$ See City of Cleburne v. Cleburne Living Ctr., Inc., 473 U.S. 432, 440 (1985) (stating that statutes classifying race, alienage, or national origin are subject to strict scrutiny).

${ }^{190}$ See Scott Burris, Fear Itself: AIDS, Herpes and Public Health Decisions, 3 YALE L. \& POL'Y REV. 479, 491-96 (1985) (discussing standards for assessing medical risks).

${ }^{191} 422$ U.S. 563, 575-76 (1975).

${ }^{192}$ See, e.g., Suzuki v. Yen, 617 F.2d 173, 178 (9th Cir. 1980) (affirming the district court's holding that involuntary commitment of mental patients under Hawaii statute is unconstitutional due to the legislature's failure to specify that the patients' danger to themselves or others must be "imminent").

${ }^{193}$ While courts defer to the professional judgment of health officials, they do require a finding of dangerousness. See, e.g., State v. Snow, 324 S.W.2d 532, 534 (Ark. 1959) (basing rationale for involuntary commitment to a sanitarium for tuberculosis on "the theory that the public has an interest to be protected"); In re Halko, 54 Cal. Rptr. 661 (Cal. Ct. App. 1966) (finding isolation of person with tuberculosis does not deprive that person of due process if the health officer has reasonable grounds to believe he is dangerous); Moore v. Draper, 57 So. 2d 648, 650 (Fla. 1952) (noting that when a person's disease is arrested to the point where he is no longer a danger, he may seek release); Moore v. Armstrong, 149 So. 2d 36, 37 (Fla. 1963) (supporting the ruling in Moore v. Draper that civil commitment of limited time is constitutional).

194614 N.Y.S.2d 8, 9 (App. Div. 1994); See City of York v. Antoinette R., 630 N.Y.S.2d 1008 (Sup. Ct. 1995) (granting order detaining woman with active tuberculosis who left the hospital against medical advice, missed observed therapy appointments, threw out medicine in the presence of a Public Health Advisor, and repeatedly admitted herself to the hospital using aliases). 
entire class would fail to take their medication would restrain the liberty of those who would, in fact, comply. The Supreme Court is more tolerant of under-inclusive interventions-i.e., those that restrain some, but not all, dangerous persons. Yet, if the under-inclusion was arbitrary, or worse, purposefully discriminatory, it could be constitutionally invalid. For example, confinement of gay men with HIV, but not others who engage in unsafe sex, would be prejudicial and, arguably, unconstitutional.

The least restrictive alternative.-Given the strict standard of review in cases involving deprivation of liberty, the state would not be permitted to resort to confinement if it could achieve its objectives through less drastic means. ${ }^{195}$ For example, if the state could avoid deprivation of liberty by directly observe therapy, it could be required to do so. However, the state probably does not have to go to extreme, or unduly expensive, means to avoid confinement. ${ }^{196}$ For example, the judiciary would be unlikely to require the government to provide economic services, benefits, and incentives to persuade individuals to take their medication. ${ }^{197}$ Nor must the state adopt less effective measures. In the context of tuberculosis, New York City health officials aptly argued that it could not be required "to exhaust a pre-set, rigid hierarchy of alternatives that would ostensibly encourage voluntary compliance ... regardless of the potentially adverse consequences to the public health." 198

${ }^{195}$ See In re City of New York, 614 N.Y.S.2d at 9. The most developed expression of the right to less restrictive alternatives is in mental health cases. See, e.g., Covington v. Harris, 419 F.2d 617, 623 (D.C. 1969) (stating that "[t]he principle of the least restrictive alternative is equally applicable to alternate dispositions within a mental hospital"); Lessard v. Schmidt, 349 F. Supp. 1078, 1096 (E.D. Wis. 1972) (holding civil commitment in hospital should be a last resort).

${ }^{196}$ See Lawrence O. Gostin, The Resurgent Tuberculosis Epidemic in the Era of AIDS: Reflections on Public Health, Law, and Society, 54 MD. L. REV. 1, 108-12 (1995).

${ }^{197}$ But see City of Newark v. J.S., 652 A.2d 265 (N.J. Super Ct. Law Div. 1993) (noting that health officials usually have to show that they attempted step-bystep interventions, beginning with voluntary directly observed therapy, supplemented by incentives, such as a food or money rewards for taking medication, and enablers, such as travel assistance, with commitment as an absolute last resort).

${ }^{198}$ Response to Public Comments Concerning Proposed Amendments to Section 11.47 of the Health Code 7 (Mar. 2, 1993). 
Procedural due process.-Persons subject to detention are entitled to procedural due process. As the Supreme Court recognized, "[t]here can be no doubt that involuntary commitment to a mental hospital, like involuntary confinement of an individual for any reason, is a deprivation of liberty which the State cannot accomplish without due process of law." ${ }^{199}$ The extent of the process required depends on the nature and duration of the restraint. ${ }^{200}$ Certainly, the state must provide elaborate due process for long-term, non-emergency, detention. ${ }^{201}$ Noting that "civil commitment for any purpose constitutes a significant deprivation of liberty," 202 and that commitment "can engender adverse social consequences," the Court has held that, in a civil commitment hearing, the government has the burden of proof by "clear and convincing evidence."203

In Greene v. Edwards, ${ }^{204}$ the West Virginia Supreme Court reasoned that there is little difference between loss of liberty for mental health reasons and the loss of liberty for public health rationales. Persons with infectious disease, therefore, are entitled to similar procedural protections as persons with mental illness facing civil commitment. These procedural safeguards

${ }^{199}$ O’Connor v. Donaldson, 422 U.S. 563, 580 (Burger, C.J., concurring); see also Addington v. Texas, 441 U.S. 418, $425-27$ (1979) (explaining due process requirements for civil commitment); Vitek v. Jones, 445 U.S. 480, 491-92 (1980) (recognizing procedural due process rights for imprisoned felon seeking to be confined to mental health facility); Project Release v. Prevost, 722 F.2d 960, 971 (2d Cir. 1983) (showing that liberty may be infringed with an involuntary civil commitment).

${ }^{200}$ See Washington v. Harper, 494 U.S. 210, 229-30 (1990) (holding the extent of due process protections depends on the mentally ill patient's interest in the side effects of unwanted antipsychotic drugs).

${ }^{201}$ See, e.g., In re Ballay, 482 F.2d 648, 663-66 (D.C. Cir. 1973) (distinguishing procedural safeguards for temporary confinement and long-term confinement where patient poses threat to others); $c f$. Lessard v. Schmidt, 413 F. Supp. 1318 (E.D. Wis. 1976) (holding that federal abstention doctrine does not preclude federal court granting federal relief to challenge of state civil commitment law). But see Morales v. Turman, 562 F.2d 993 (5th Cir. 1977). "A state should not be required to provide the procedural safeguards of a criminal trial when imposing a quarantine to protect the public against a highly communicable disease." Id. at 998 (citing Jacobson v. Massachusetts, 197 U.S. 11, 29-30 (1905)).

${ }^{202}$ Addington, 441 U.S. at 425; see also Jackson v. Indiana, 406 U.S. 715, 738 (1972) (holding that "due process requires that the nature and duration of commitment bear some reasonable relation to the purpose for which the individual is committed").

${ }^{203}$ Addington, 441 U.S. at 426 (requiring that the standard of proof in commitments for mental illness be greater than the preponderance of the evidence standard, but the reasonable doubt standard is not constitutionally required).

${ }^{204} 263$ S.E.2d 661, 663 (W. Va. 1980). 
include the right to counsel, a hearing, and an appeal. Such rigorous procedural protections are justified by the fundamental invasion of liberty occasioned by long-term detention; the serious implications of erroneously finding a person dangerous; and the value of procedures in accurately determining complex facts which are important to predicting future dangerous behavior.

Thus, provided they conform with procedural due process, public health authorities have ample power to detain persons to prevent transmission of infectious disease. The person or group confined must pose a significant risk to the public and the state must exhaust less restrictive alternatives. Beyond these procedural and substantive standards, public health authorities retain considerable discretion. The courts are unlikely to apply strict scrutiny to less intrusive interventions that invade bodily integrity in less consequential ways, such as compulsory vaccination ${ }^{205}$ and testing. ${ }^{206}$ For most other public health powers such as reporting and partner notification, the courts adopt a highly deferential approach. ${ }^{207}$

\section{Beyond Levels of Constitutional Scrutiny}

Constitutional scholars, and members of the Court itself, often criticize the levels of review because they are inflexible and outcome determinative. ${ }^{208}$ Where the Court sees certain touchstones of constitutional concern such as a suspect classification or the violation of a fundamental right, the government almost invariably loses-strict scrutiny is "strict in theory, but fatal in fact." ${ }^{209}$ In the absence of these specific gages of constitutional concern, the Court uses the rational basis test and the government almost invariably wins. Certainly, different stan-

${ }^{205}$ See Zucht v. King, 260 U.S. 174 (1922).

${ }^{206}$ See Skinner v. Railway Labor Executives' Ass'n, 489 U.S. 602 (1989) (holding drug testing constitutional under the Fourth Amendment due to railroad's interest in public safety).

${ }^{207}$ See Whalen v. Roe, 429 U.S. 589 (1977) (upholding New York statute requiring patient identification for Schedule II drugs based on the State's broad police powers).

${ }^{208}$ See, e.g., San Antonio Indep. Sch. Dist. v. Rodriguez, 411 U.S. 1, 109-10 (1973) (Marshall, J., dissenting) (arguing that a principled constitutional analysis would apply a spectrum of standards depending on the nature of the right and the discriminatory effects).

${ }^{209}$ Fullilove v. Klutznick, 448 U.S. 448, 519 (1980) (Marshall, J., concurring) (citing Regents of Univ. of Cal. v. Bakke, 438 U.S. 265, 362 (1978) (joint separate opinion)). 
dards ought to apply depending on the class used or the right infringed. Yet, it is far from clear why such sharply different constitutional standards, and outcomes, should result. Strict scrutiny is invoked for classifications based on race, national origin, and alienage, but not sexual orientation, ${ }^{210}$ disability, ${ }^{211}$ or socio-economic status. ${ }^{212}$ Yet, each of these groups has experienced discrimination based on irrational fears and prejudices. Similarly, strict scrutiny is invoked for invasions of fundamental interests such as contraception, abortion, and interstate travel, but not for breaches of confidentiality ${ }^{213}$ or interference with the doctor/patient relationship. ${ }^{214}$ Yet, each of these liberty interests has importance to human dignity and individual freedom. Whatever differences exist between various status classifications and liberty interests, they are differences of degree, not of kind.

At the same time, when the Court applies rationality review, it fails to ask public health authorities to justify their actions in the most elemental ways: What are the specific public health goods sought by the intervention? What scientific evidence exists demonstrating a significant health risk? Are the interventions proposed likely to be effective?

Two problems, then, are evident in constitutional analysis. First, the standards provide a rigid "all-or-nothing" assessment, rather than a graduated examination based on the burdens posed by discriminatory classifications or infringements on autonomy, privacy, and liberty. Second, under rationality review, by far the most common form of scrutiny, there are few demands placed on public health authorities to justify their actions based on scientific evidence of risk reduction.

For a different way of thinking about levels of constitutional review, think of a sliding scale that subjects public health

${ }^{210}$ See Bowers v. Hardwick, 478 U.S. 186 (1986) (applying rational basis test to uphold a state statute prohibiting sodomy).

${ }^{211}$ See Heller v. Doe, 509 U.S. 312 (1993) (applying rational basis test to uphold civil commitment of mentally ill, and applying stricter standards to mentally retarded persons); see also City of Cleburne v. Cleburne Living Ctr., Inc., 473 U.S. 432 (1985) (using rational basis test to invalidate a zoning ordinance that prevented the construction of a group home for persons with mental retardation).

${ }^{212}$ See San Antonio Indep. Sch. Dist., 411 U.S. at 40-44.

${ }^{213}$ See Whalen, 429 U.S. at 603-04 (upholding state statute requiring that the state be provided with every prescription for certain types of drugs).

${ }^{214}$ See Washington v. Glucksberg, 521 U.S. 702, 719 (1997) (upholding state statute prohibiting the causation or assistance of suicide). 
policies to increasingly demanding levels of constitutional review. As the intrusiveness and unfairness of the public health policy grows, so would the level of scrutiny. As a policy moves across the continuum because of its restrictive or discriminatory quality, public health would gradually give way to individual liberty (see Figure 1).

FIGURE 1

Evaluating THE CONSTITUTIONALITY OF

Public Health Policies

A Proposal for a Graduated Approach

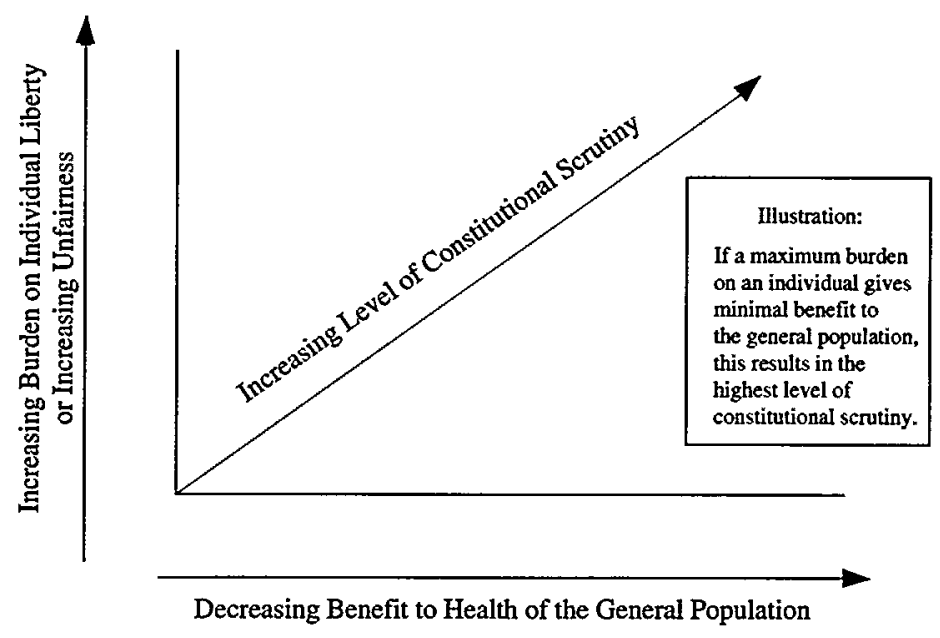

\section{ECONOMIC LIBERTY AND THE PURSUTT OF PUBLIC HEALTH}

Public health regulation does not merely restrict personal liberties. It also undoubtedly interferes with economic liberties. The Framers clearly intended to protect economic liberties, as evidenced by several constitutional provisions. Notably, the Constitution forbids the state from depriving persons of property (or life or liberty) without due process of law (economic 
due process) ${ }_{216}^{215}$ impairing the obligations of contracts (freedom of contract), ${ }^{216}$ and taking private property for public use without just compensation ("takings"). ${ }^{217}$ In this Part, I will examine the normative and constitutional justifications for economic liberties.

\section{A. Economic Due Process}

Conservative scholars argue that economic liberties are important in the constitutional design and observe that the Supreme Court has, at times, strongly protected commercial relationships. ${ }^{218}$ However, on more careful reflection, the Court has more often seen public health regulation as a sufficient justification for government infringement of economic freedom. Not long after the Constitution was ratified, the Supreme Court explored the idea that private property deserved protection as part of the natural law. ${ }^{219}$ However, none of these early cases involved public health regulation. Indeed, when the Supreme Court came to examine a challenge to sanitary regulation of slaughter houses in 1873 , it said that government had the un-

215 The Fifth and Fourteenth Amendments, respectively, provide that neither the federal government nor the states shall deprive any person of "life, liberty, or property without due process of law."

${ }^{216}$ U.S. CoNST. art. I, $\S 10$, cl. 1 ("No State shall . . p pass any . . . Law impairing the obligations of Contracts").

${ }^{217}$ U.S. CONST. amend. V ("nor shall private property be taken for public use, without just compensation").

218 For early conservative scholarship, see HERBERT SPENCER, SOCIAL STATICs 265-66 (Robert Schalkenbach Found. 1954) (1851) (advocating a laissezfaire, unregulated economy); Christopher G. TIEDEMAN, A Treatise ON THE Limitations of THE Police Power IN THE UNITEd STATES (Da Capo Press 1971) (1886) (stating that government regulations unduly interfere with the natural rights of people to own and use property). For more recent accounts, see generally RICHARD A. Epstein, TAKings: Private Property AND the Power of EMINENT Domain (1985) (describing individual liberty protections, based primarily on economic theory, in light of state action); BERNARD H. SIEGAN, ECONOMIC LIBERTIES AND THE CONSTITUTION (1980) (stating that scholars have accepted the position that the Constitution does not give the national judiciary power to outlaw federal or state regulations relating to economic activity).

219 See, e.g., Calder v. Bull, 3 U.S. 386 (1798) (holding that Connecticut ex post facto law was a taking of property from innocent parties and was counter to natural law and the Constitution); Fletcher v. Peck, 10 U.S. (6 Cranch) 87 (1810); Terrett v. Taylor, 13 U.S. (9 Cranch) 43 (1815) (finding that a private entity may dispose of its property however it deems fit). 
doubted power to restrict occupational freedoms for the common good. ${ }^{220}$

During the nineteenth century, the Court began to find that business regulation could violate due process, but still, when it came to public health, it affirmed the state's power. ${ }^{221}$ The Lochner era, from 1905 to 1937, was a time when the Court most prized economic freedoms and aggressively invalidated numerous attempts at social and economic regulation. Certainly, the Court struck down important health and social legislation protecting trades unions, ${ }^{222}$ setting minimum wages for women, ${ }^{223}$ protecting consumers from products that posed health risks, ${ }^{224}$ and licensing or regulating businesses. ${ }^{225} \mathrm{Nev}-$ ertheless, as evidenced by its decision in Jacobson v. Massachusetts, ${ }^{226}$ the Court conceded, at least nominally, that the state could exercise its police power even if it interfered with liberty. Since Roosevelt's New Deal, the Court has granted police power regulation a strong presumption of validity even if it interferes with economic and commercial life.

\section{B. Freedom of Contract}

While some scholars espouse a belief in free economic relationships, the contracts clause has become a relatively unimportant limitation on public health powers. The clause applies only to the states; challenges to federal restrictions on contractual freedom must be brought under the due process clause. Moreover, the clause applies only to existing contracts; states

${ }^{220}$ See The Slaughter-House Cases, 83 U.S. 36, 81 (1873) (noting that "under no construction of [due process]...can the restraint...upon the exercise of their trade...be held to be a deprivation of property..."); See also Wendy E. Parmet, From Slaughter-House to Lochner: The Rise and Fall of the Constitutionalization of Public Health, 40 AM. J. LEGAL HIST. 476 (1996).

${ }^{221}$ See Mugler v. Kansas, 123 U.S. 623 (1887) (upholding state prohibition on the sale of alcoholic beverages).

${ }^{222}$ See Coppage v. Kansas, 236 U.S. 1 (1915) (invalidating federal and state legislation forbidding employers to require employees to agree not to join a union).

${ }^{223}$ See Adkins v. Children's Hosp., 261 U.S. 525 (1923) (invalidating a law establishing minimum wages for women).

224 See Weaver v. Palmer Bros. Co., 270 U.S. 402 (1926) (striking down law that prohibited use of rags and debris in mattresses enacted to protect the public health pursuant to the Due Process Clause of the Fourteenth Amendment).

${ }^{225}$ See New State Ice Co. v. Liebmann, 285 U.S. 262 (1932) (striking down a statute forbidding a state commission to license the sale of ice except on proof of necessity). 
are free to limit the terms of future contracts. ${ }^{227}$ While most public health regulation affects future economic relationships, it sometimes can affect existing contracts. The Supreme Court, however, has emphasized that the police power "is an exercise of the sovereign right of the Government to protect the lives, health, morals, comfort and general welfare of the people, and is paramount to any rights under contracts between individuals."228

The modern Court uses a three part test to assess government regulation that interferes with private contracts: ${ }^{229}$ (1) Is there a substantial impairment of a contractual relationship? (2) If so, does it serve a significant and legitimate public purpose? and (3) Is it reasonably related to achieving the goal? ${ }^{230}$ Like substantive due process, this is a highly permissive standard that generally affirms governmental power to regulate contractual relationships reasonably in the public interest.

\section{Regulatory "Takings"}

Attorney General Meese . . . had a specific, aggressive, and, it seemed to me, quite radical project in mind: to use the Takings Clause of the Fifth Amendment as a severe brake on federal and state regulation of business and property.

\section{Charles Fried (1991) 231}

[M] any of the changes in takings law ... correspond quite closely to a blueprint for takings doctrine proposed by Professor Richard Epstein. . . . This observation [is] both remarkable and troubling. After all, Epstein's work was almost universally criticized ... [ and its] proposed end result - the overturning of a century's worth of health, safety, and economic regulation--

${ }^{227}$ See Ogden v. Saunders, 12 U.S. (5 Wheat.) 213 (1827).

${ }^{228}$ Manigault v. Springs, 199 U.S. 473, 480 (1905).

${ }^{229}$ A more stringent test is used for interference with government contracts. See United States Trust Co. v. New Jersey, 431 U.S. 1 (1977).

${ }^{230}$ See Energy Reserves Group, Inc. v. Kansas Power \& Light Co., 459 U.S. $400,411-13$ (1983) (explaining the requisite inquiry to discovering a violation of the Contract Clause).

${ }^{231}$ Charles Fried, ORder and Law: ARguing the Reagan RevolutionA FIRSTHAND ACCOUNT 183 (1991) (citations omitted). 
would sink this country in a constitutional crisis. . . . What we [have] found is a large and increasingly successful campaign by conservatives and libertarians to use the federal judiciary to achieve an anti-regulatory, anti-environmental agenda.

Douglas T. Kendall \& Charles P. Lord (1998) ${ }^{232}$

The federal government and the states have the power of eminent domain, which is the authority to confiscate private property for a governmental activity. However, the Fifth Amendment imposes a significant constraint on this power by requiring "just compensation" for private property taken for a public use. ${ }^{233}$ The theory behind the takings clause is that individuals should not have to bear public burdens which should be borne by the community as a whole. Consequently, the takings clause is about government spreading loss when pursuing the public interest. ${ }^{234}$

Despite its just purposes, an expansive interpretation of the takings clause would shackle public health agencies. by requiring them to provide compensation whenever regulation significantly reduced the value of private property. Since public health regulation, by definition, restricts commercial uses of property, it has become a focal point for a sustained conservative critique of social action itself. ${ }^{235}$

${ }^{232}$ Douglas T. Kendall \& Charles P. Lord, The Takings Project: A Critical Analysis and Assessment of the Progress So Far, 25 B.C. ENVTL. AFF. L. REv. 509, 510 (1998) (referring to Richard A. EPSTEIN, TAKINGS, PRIVATE PROPERTY AND THE POWER OF EMINENT DOMAIN (1985)) (citations omitted).

${ }^{233}$ See generally Jed Rubenfeld, Usings, 102 YALE L.J. 1077 (1993) (providing an overview of takings law, eminent domain, and the Just Compensation Clause); ROBERT MELTZ ET AL., THE TAKINGS ISSUE: CONSTITUTIONAL LIMITS ON LAND-USE CONTROL AND ENVIRONMENTAL REgulation (1999); S'TEVEN J. EAGLE, REGULATORY TAKINGS $\$ 1-5$, at 9 (1996) (discussing various cases interpreting the extent of the government's power to take property).

${ }^{234}$ See Eastern Enters. v. Apfel, 524 U.S. 498, 522-24 (1998) (per O'Connor, J., with three Justices joining and one Justice concurring in the judgment) (explaining the aim of the Takings Clause of the Fifth Amendment); see also Frank I. Michelman, Property, Utility, and Fairness; Comments on the Ethical Foundations of "Just Compensation" Law, 80 HARv. L. REv. 1165 (1967) (investigating compensable and noncompensable government taking and underlying theory, fairness, judicial, and legislative roles).

${ }^{235}$ See EPSTEIN, supra note 218, at 100-04. 
Government confiscation or physical occupation of property is a "possessory" taking that certainly requires compensation. During the early twentieth century, however, the Supreme Court held that government regulation which "reaches a certain magnitude" also is a taking requiring compensation. ${ }^{236}$ Initially, this idea of "regulatory" takings was not highly problematic for public health agencies because the Court suggested that government need not compensate property owners when regulating within the police power. ${ }^{237}$ However, regulatory takings took on public health significance in the 1992 case of Lucas $v$. South Carolina Coastal Council. ${ }^{238}$ In Lucas, Justice Scalia, the most intellectually powerful conservative voice on the Court, said that a person suffers a taking if regulation denies all economically beneficial or productive use of real property ${ }^{239}$ and there were no similar restrictions "that background principles of the State's law of property and nuisance already place upon land ownership." 240 Justice Scalia suggested that common law nuisance was the key to resolving the question of when regulation amounted to an uncompensated taking; an owner who lost the value of her land would suffer a taking if the public health regulation was not considered a nuisance under the common law.

${ }^{236}$ Pennsylvania Coal Co. v. Mahon, 260 U.S. 393, 413 (1922) (discussing that when some property rights are very limited under the police powers of the state, there may need to be an act of eminent domain plus compensation).

${ }^{237}$ See id. (stating that "[a]s long recognized, some values are enjoyed under an implied limitation and must yield to the police power"); see also, e.g., Catherine R. Connors, Back to the Future: The "Nuisance Exception" to the Just Compensation Clause, 19 CAP. U. L. REv. 139, 153-58 (1990) (discussing the history and development of the nuisance exception within regulatory takings); Joseph L. Sax, Takings and the Police Power, 74 YALE L.J. 36 (1964) (analyzing "takings" cases where lawful exercise of police power was held to be noncompensable because losses were incidental).

238505 U.S. 1003 (1992); see also Richard J. Lazarus, Putting the Correct "Spin" on Lucas, 45 STAN. L. REV. 1411 (1993)(arguing that the requirement for just compensation on any regulatory takings may obstruct public health policy).

${ }^{239}$ Regulatory takings doctrine applies to real property (real estate or land) and not to personal property (e.g., commercial activities such as manufacture or sale): "[B]y reason of the State's traditionally high degree of control over commercial dealings, he ought to be aware of the possibility that new regulation might even render his property economically worthless...." Lucas, 505 U.S. at 1027-28.

240 Id. at 1029. The Court has also said that police power regulation becomes a taking if the burden imposed is not roughly proportionate to the government's justification for regulating. See Dolan v. City of Tigard, 512 U.S. 374, 389-91 (1994). 
The Court's reasoning in Lucas is problematic because it forces public health authorities to define and abate public hazards according to vague and outdated common law understandings of nuisance. Even the most astute legal scholars perceive common law nuisance as confusing and indecipherable. ${ }^{241} \mathrm{Con}-$ sequently, when democratically elected government, according to modern standards, regulates to avert a serious public harm, it cannot be certain whether it will be compelled to compensate property owners. This narrowing of what may be considered a nuisance, and expansion of property interests, effectively constrains police power regulation. The Court, in effect, has simultaneously frozen the understanding of public health that existed in earlier times, while allowing the normative value of property to expand to meet modern libertarian expectations.

Since Lucas, state and lower federal courts often have resisted expansion of the takings doctrine, ruling against compensation resulting from environmental regulation. ${ }^{242}$ However, other courts have used the "property rights" tenor of Justice Scalia's opinion to strike down important public health and environmental regulation. ${ }^{243}$ The Court of Appeals for the Federal Circuit established a rule that government may have to compensate an owner for any regulation that causes a diminution in value, unless there is a "reciprocity of advantage" by which the owner receives "direct compensating benefits." "244 This kind of balancing appears to place private property interests on a par with the state's sovereign interests in community well-being. Takings litigation can penetrate deeply into core public health

${ }^{241}$ See, e.g., Lucas, 505 U.S. at 1055 (Blackman, J., dissenting) (noting that "one searches in vain...for anything resembling a principle in the common law of nuisance"); William L. Prosser, Nuisance Without Fault, 20 TEx. L. REv. 399, 410 (1942) (describing common law nuisance as a "legal garbage" full of vagueness, uncertainty, and confusion).

${ }^{242}$ See, e.g., Gazza v. New York State Dep't of Envtl. Conservation, 679 N.E.2d 1035 (N.Y. 1997) (protecting wetlands by finding that there was no taking of property interest); Anello v. Zoning Bd. of Appeals, 678 N.E.2d 870 (N.Y. 1997) (holding that the denial of a variance from the "steep slope" ordinance which prevented the owner from building a family home did not constitute a taking).

${ }^{243}$ See Loveladies Harbor, Inc. v. United States, 28 F.3d 1171 (Fed. Cir. 1994) (holding trial court did not err when it held that government's denial of development permit based on the Clean Water Act was a taking); Preseault v. United States, 100 F. 3d 1525 (Fed. Cir. 1996) (requiring the State of Vermont to compensate land owners for the taking of property).

${ }^{244}$ Florida Rock Indus. v. United States, 18 F.3d 1560, 1570-71 (Fed. Cir. 1994). 
concerns. Consider the federal court decision upholding Philip Morris's claim that a Massachusetts law requiring manufacturers to disclose the ingredients in cigarettes was a regulatory taking. ${ }^{245}$

If Charles Fried was correct in describing a conservative plan to use the takings clause as a severe constraint on public health regulation, then the outcome remains uncertain. Much depends on the direction of the Supreme Court which, at present, has four members apparently committed to expansion of the regulatory takings doctrine. ${ }^{246}$ This split among the Justices was manifested in a 1998 case when a bitterly divided Court said that some public programs allocating benefits and burdens of economic life to promote the common good effect a taking. The plurality, representing the four-member conservative bloc on this issue, supported a balancing test (i.e., "the character of the government's action, its economic impact, and its interference with reasonable, investment-backed expectations") that elevates economic justice to a new level in our constitutional democracy. ${ }^{247}$

\section{The Normative Value of Economic Liberty}

Government regulation for the public's health, as we have seen throughout this article, inevitably interferes with personal or economic liberties. The Court usually grants the legislature deference in the exercise of police powers. A permissive approach to government regulation is justified, in part, by democratic values; citizens elect representatives to enable them to make complex policy choices. ${ }^{248}$ A legislative choice to prefer

245 Philip Morris, Inc. v. Reilly, 113 F. Supp. 2d 129 (D. Mass. 2000); Philip Morris, Inc. v. Harshbarger, 159 F.3d 670 (1st Cir. 1998) (upholding Philip Morris's challenge to ingredient reporting requirements under Massachusetts law); Ruckelshaus v. Monsanto Co., 467 U.S. 986, 1004-14 (1984) (upholding, in part, a pesticide manufacturer's claim that compelled disclosure of trade secrets constituted a regulatory taking).

${ }^{246}$ The four consistent voices favoring an expansive reading of the takings clause are Chief Justice Rehnquist and Justices Scalia, Thomas, and O'Connor. See Lazarus, supra note 238, at 1412-16 (reviewing the judicial opinions of Supreme Court Justices on property takings cases); see also Kendall \& Lord, supra note 232, at 583-84.

${ }^{247}$ Eastern Enters. v. Apfel, 524 U.S. 498, 526-27 (1998); City of Monterey v. Del Monte Dunes at Monterey, Ltd., 526 U.S. 687 (1999).

${ }^{248}$ See, e.g., Miller v. Schoene, 276 U.S. 272 (1928). "When forced to such a choice the state does not exceed its constitutional powers by deciding upon the de- 
collective health and well-being over individual interests deserves respect and insulation from aggressive judicial scrutiny. This is broadly the judicial approach to public health regulation affecting personal autonomy, as the Jacobson case illustrates. Heightened scrutiny is reserved for those rare instances where public health interventions intrude on fundamental rights and interests, such as total deprivation of liberty.

The normative issue is whether there is something in the nature of economic liberty that warrants a departure from the normal deference to public health regulation. Put another way, how important is unbridled freedom in property uses, financial relationships, and the pursuit of occupations? I see no reason why the diminution of economic liberties should be taken more seriously than the many deprivations of personal autonomy and privacy that routinely occur with public health regulation (e.g., vaccination, reporting, and contact tracing). Courts generally understand that some loss of individual freedom is necessary for the common welfare. Regulation that interferes with civil liberties does not cause conservative thinkers undue concern; nor is there any discussion of compensation to those who must forgo liberty for the collective good.

The same logic ought to apply to economic regulation for the common welfare. The reason for the governmental intervention is to prevent owners from using their private property in ways that are harmful to the public interest. Thus, the state's aim is not to deny economic opportunity per se, but only to foreclose commercial activities that are detrimental to public health and safety. The creation of private wealth, moreover, hardly can be regarded as a fundamental interest akin to total loss of personal freedom, for private wealth creation it is not essential to the achievement of a healthy and fulfilling life. Rarely does economic regulation affect an individual's basic ability to obtain the necessities of life, such as food, shelter, and medical care.

The conservative claim, of course, is not only that economic liberties have intrinsic value, but that they also have instrumental value. They claim that preserving economic liberty will help create wealth for the community-at-large. Even assuming that economic freedom reliably leads to greater overall 
prosperity, it is still reasonable for a legislature to make a social choice that favors immediate health and safety benefits over future wealth creation. A community cannot benefit from increased prosperity if it experiences excess morbidity and mortality from hazardous commercial activity.

Government, to be sure, ought not carelessly or gratuitously interfere with economic freedoms. If government has a reason, however, based on averting a significant risk to the public's health, then there appears nothing in the nature of economic liberty that should prevent the state from intervening; nor is there any reason why the state should provide compensation for regulating private commercial activities deemed detrimental to the communal good.

\section{CONCLUSION}

The role of public health in the constitutional design is complex, raising intellectually intriguing issues about government duty, power, and limits. The Court's jurisprudence on government obligation to assure the conditions for the public's health has been uninspiring. The Court continues to read the Constitution as a defensive document, void of any affirmative duty to protect the public's health and safety. Hiding behind a flawed distinction between acts and omissions, the Court permits government to promise social protection but conspicuously fail to fulfill its promise.

Throughout its history, the judiciary has largely deferred to the legislative and executive branches of government in the exercise of public health powers. In its earliest traditions, the Court embraced the idea of the social contract. Even in later jurisprudence where the Court purportedly engaged in more rigorous forms of scrutiny, it rarely found occasion to overturn the authority public health officials. Undoubtedly, personal autonomy, privacy, and liberty are exceptionally important values. However, they do not necessarily trump the equally important collective value of community health and wellbeing.

Currently, we live an in age that is hostile to public health. Approximately one percent of all health care dollars are spent on population-based services; the rest (excluding environmental expenditures) are spent on personal medical services largely within the private sector. The public has an antipathy for government (particularly central government), believing that the 
state inherently cannot operate fairly or efficiently. People seek lower tax burdens, believing that the state should not deprive individuals of their hard-earned incomes. Finally, the public rejects regulation, believing that it stifles private enterprise and improperly interferes with economic freedom.

History teaches that the Justices are not immune to public opinion and do insert their own ideologies into the jurisprudence. It is no secret that a majority of the modern Court is conservative. In one sense this may benefit public health, for it is part of the conservative judicial philosophy to defer to state action. However, in another sense, the current conservative judicial climate may be critically harmful to public health. The Court is undertaking a sustained project to deprive the federal government of much of its authority to intervene in matters of the environment and the public's health. At the same time, conservatism stresses the importance of economic liberty, which is anti-regulatory in its tone and effects.

The Court's role in matters of reproductive freedom is widely acknowledged. Less well understood, however, is the importance of future appointments to the Court in the realm of public health. The Supreme Court is bitterly divided on many conservative projects that are meaningful to public health-e.g., new federalism and regulatory "takings." The modern Court is poised to threaten the viability of a broad range of regulatory activities to protect human health and the environment. The power of Congress, and even the states, to respond effectively to health or environmental threats depends very much on the Court's future constitutional adjudication. 


\section{APPENDIX A}

\begin{tabular}{|c|c|c|c|}
\hline \multicolumn{4}{|c|}{$\begin{array}{c}\text { Table } 1 \\
\text { The Federal Agency Role in Public Health }\end{array}$} \\
\hline $\begin{array}{l}\text { U.S. } \\
\text { Dept. }\end{array}$ & Agency & Date/Authority & $\begin{array}{l}\text { Public Health } \\
\text { Function }\end{array}$ \\
\hline HHS & $\begin{array}{l}\text { Health and } \\
\text { Human } \\
\text { Resources }\end{array}$ & $\begin{array}{l}1798 \text { Marine Hospital } \\
\text { Service est. fore- } \\
\text { runner of HHS } \\
1953 \text { HEW est. ( } 5 \text { USC } \\
\text { app) } \\
1980 \text { HHS est. }\end{array}$ & \\
\hline HHS & $\begin{array}{l}\text { Public Health } \\
\text { Service }\end{array}$ & $\begin{array}{l}1798 \text { Marine Hospital } \\
\text { Service est. } \\
1902 \text { Public Health and } \\
\text { Marine Hospital } \\
\text { Service est. } \\
1912 \text { Public Health } \\
\text { Service est. } \\
1995 \text { reorganized } \\
\text { (Fed. Reg. 60, No. } \\
\text { 217) } \\
\end{array}$ & \\
\hline HHS & $\begin{array}{l}\text { Administration } \\
\text { on Aging }\end{array}$ & $\begin{array}{l}1961 \text { First White House } \\
\text { Conference on } \\
\text { Aging } \\
1965 \text { Admin. on Aging } \\
\text { est. under the } \\
\text { Older Americans } \\
\text { Act (amended in } \\
\text { 42 USC } 3001 \text { et } \\
\text { seq.) } \\
\end{array}$ & . \\
\hline HHS & $\begin{array}{l}\text { Administration } \\
\text { for Children } \\
\text { and Families }\end{array}$ & $\begin{array}{l}1991 \text { est. under } \S 6 \text { of } \\
\text { Reorganization } \\
\text { Plan No. } 1 \text { of } \\
1953\end{array}$ & $\begin{array}{l}\text { Provides executive } \\
\text { direction and guid- } \\
\text { ance relating to } \\
\text { issues surrounding } \\
\text { children and fami- } \\
\text { lies }\end{array}$ \\
\hline HHS & $\begin{array}{l}\text { Agency for } \\
\text { Health Care } \\
\text { Policy and } \\
\text { Research }\end{array}$ & $\begin{array}{l}1989 \text { est., reorganized } \\
\text { Oct. 31, 1995 } \\
\text { (42 USC 299) }\end{array}$ & $\begin{array}{l}\text { Provides resources } \\
\text { for research }\end{array}$ \\
\hline
\end{tabular}




\begin{tabular}{|c|c|c|c|}
\hline \multicolumn{4}{|c|}{$\begin{array}{c}\text { Table } 1 \\
\text { The Federal Agency Role IN Public Health }\end{array}$} \\
\hline $\begin{array}{l}\text { U.S. } \\
\text { Dept. }\end{array}$ & Agency & Date/Authority & $\begin{array}{c}\text { Public Health } \\
\text { Function }\end{array}$ \\
\hline HHS & $\begin{array}{l}\text { Agency for } \\
\text { Toxic } \\
\text { Substances } \\
\text { and Disease } \\
\text { Registry }\end{array}$ & $\begin{array}{l}1980 \text { est. } \\
1986 \text { received addi- } \\
\text { tional responsi- } \\
\text { bilities with } \\
\text { passage of Super- } \\
\text { fund Amend- } \\
\text { ments and } \\
\text { Reauthorization } \\
\text { Act, reorganized } \\
\text { Oct. } 31,1995 \\
\end{array}$ & $\begin{array}{l}\text { Aims to prevent } \\
\text { exposure and sub- } \\
\text { sequent harmful } \\
\text { effects from haz- } \\
\text { ardous substances in } \\
\text { the environment }\end{array}$ \\
\hline HHS & $\begin{array}{l}\text { Centers for } \\
\text { Disease } \\
\text { Control and } \\
\text { Prevention }\end{array}$ & $\begin{array}{c}1942 \text { Office of National } \\
\text { Defense Malaria } \\
\text { Control Activi- } \\
\text { ties est. } \\
1942 \text { Office of Typhus } \\
\text { Fever Control est. } \\
1946 \text { Communicable } \\
\text { Disease Center } \\
\text { est. } \\
1970 \text { Centers for Dis- } \\
\text { ease Control est. } \\
1973 \text { est. , reorganized } \\
\text { Oct. } 31,1995 \\
\end{array}$ & $\begin{array}{l}\text { Provides leadership } \\
\text { and coordination in } \\
\text { efforts to prevent } \\
\text { and control dis- } \\
\text { eases, unhealthy } \\
\text { conditions and re- } \\
\text { sponses to health } \\
\text { emergencies }\end{array}$ \\
\hline HHS & $\begin{array}{l}\text { Food and Drug } \\
\text { Administration }\end{array}$ & $\begin{array}{l}1862 \text { Bureau of Chem- } \\
\text { istry est. } \\
1907 \text { Food and Drug } \\
\text { Act passed } \\
1931 \text { FDA est. under } \\
\text { the Agriculture } \\
\text { Appropriation } \\
\text { Act (46 Stat. } \\
\text { 392), reorganized } \\
\text { Oct. 31, 1995 }\end{array}$ & $\begin{array}{l}\text { Ensures that food, } \\
\text { drugs, cosmetics, } \\
\text { and medical devices } \\
\text { are safe and effec- } \\
\text { tive }\end{array}$ \\
\hline HHS & $\begin{array}{l}\text { Health Care } \\
\text { Financing } \\
\text { Administration }\end{array}$ & 1977 est. & $\begin{array}{l}\text { Serves the elderly, } \\
\text { disabled and poor } \\
\text { Americans through } \\
\text { the administration } \\
\text { and oversight of the } \\
\text { Medicare and } \\
\text { Medicaid programs }\end{array}$ \\
\hline
\end{tabular}




\begin{tabular}{|c|l|l|l|}
\hline \multicolumn{2}{|c|}{ TABLE 1 } \\
THE FEDERAL AGENCY ROLE IN PUBLIC HEALTH
\end{tabular}




\begin{tabular}{|c|l|l|l|}
\hline \multicolumn{4}{|c|}{ TABLE 1 } \\
THE FEDERAL AGENCY RoLE IN PUBLIC HEALTH
\end{tabular}

